\title{
DO DOMESTIC INVESTORS HAVE MORE VALUABLE INFORMATION ABOUT INDIVIDUAL STOCKS THAN FOREIGN INVESTORS?
}

\author{
Hyuk Choe \\ Bong-Chan Kho \\ René M. Stulz \\ Working Paper 8073 \\ http://www.nber.org/papers/w8073 \\ NATIONAL BUREAU OF ECONOMIC RESEARCH \\ 1050 Massachusetts Avenue \\ Cambridge, MA 02138 \\ January 2001
}

We are grateful for comments from seminar participants at the Ohio State University, the Hong Kong University of Science and Technology, the University of Texas, the Hallym University, and from Andrew Karolyi. The views expressed herein are those of the authors and not necessarily those of the National Bureau of Economic Research.

(C) 2001 by Hyuk Choe, Bong-Chan Kho, and René M. Stulz. All rights reserved. Short sections of text, not to exceed two paragraphs, may be quoted without explicit permission provided that full credit, including $($ ) notice, is given to the source. 
Do Domestic Investors Have More Valuable Information About Individual Stocks Than Foreign Investors?

Hyuk Choe, Bong-Chan Kho, and René M. Stulz

NBER Working Paper No. 8073

January 2001

JEL No. G11, G14

\begin{abstract}
$\underline{\text { ABSTRACT }}$
Using trade data from Korea from December 1996 to November 1998, we find evidence that domestic individual investors have a short-lived private information advantage for individual stocks over foreign investors, but almost no evidence that domestic institutional investors have such an advantage. Foreign investors trade at worse prices than resident investors for large trades, for smaller stocks, and more so for sales than for purchases. Foreign investors sell to domestic investors before a stock has a large positive abnormal return and buy from domestic investors before a stock has a large negative abnormal return. Using intraday data, the large trades of domestic individual investors have more information than the large trades of foreign investors or of domestic institutional investors.
\end{abstract}

Hyuk Choe

Seoul National University

College of Business Administration

Seoul 151-742

Korea

Bong-Chan Kho

Seoul National University

College of Business Administration

Seoul 151-742

Korea
René M. Stulz

Everett D. Reese Chair of Banking and Monetary Economics

The Ohio State University

806A Fisher Hall

Columbus, OH 43210

and NBER

stulz@cob.ohio-state.edu 


\section{Introduction.}

Much of the international finance literature emphasizes that foreign investors are different from domestic investors. A stylized fact of the international finance literature is the existence of the home bias. With the home bias, investors overweight the domestic market in their portfolios. Despite the dramatic increase in cross-border equity and bond transactions over the last 20 years, the home bias has not disappeared. A number of attempts have been made to explain the home bias. One recurring theme in the literature is that foreign investors are less well informed about domestic securities than domestic investors, so that they are at a disadvantage trading and holding these securities. ${ }^{2}$ Recently, the informational disadvantage of foreign investors has been used as the foundation of models that attempt to explain contagion across markets and why equity flows are volatile. ${ }^{3}$ In this paper, we examine whether domestic investors have an information advantage over foreign investors because they have access to private information about individual stocks using a dataset of all trades on the Korea Stock Exchange (KSE) from December 2, 1996, to November 30, 1998. This dataset provides us with information about the buyers and sellers in all trades, including whether they are domestic or foreign investors and whether they are individual or institutional investors.

In many ways, it seems surprising that so much emphasis has been put on differences between domestic and foreign investors. After all, most international equity investment takes place through institutional investors. Usually, foreign institutional investors have access to both international expertise and talent and have considerable local resources. It is therefore not obvious that a foreign institutional investor should be at a disadvantage relative to domestic institutional investors. Grinblatt and Keloharju (2000) and Seasholes (2000) even argue that as a result of their better access to expertise and talent, foreign institutions should be smarter than local institutions. Using daily data for the 16 largest Finnish stocks, Grinblatt and Keloharju (2000) find that over a two-year period foreigners and domestic financial

\footnotetext{
${ }^{1}$ See French and Poterba (1991), Cooper and Kaplanis (1998), Tesar and Werner (1995), and Kang and Stulz (1997).

2 See Brennan and Cao (1997) for example.

${ }^{3}$ See Calvo and Mendoza (2000).
} 
corporations buy more stocks that perform well over the next 120 trading days than domestic individual investors, but their sample period is too short for them to conduct a study of holding period returns. Seasholes (2000) finds that foreign investors buy (sell) ahead of good (bad) earnings announcements in Taiwan while local investors do the opposite. These papers therefore are consistent with better information and greater sophistication on the part of foreign investors. However, evidence on the performance of foreign investors is mixed. For instance, Kang and Stulz (1997) using annual data for 18 years find no evidence that foreign investors outperform domestic investors in Japan. Hau (2000), using trade by trade data, shows that distance from Frankfurt disadvantages proprietary traders trading in German stocks. Coval and Moskowitz (1999), using only U.S. stock returns, provide evidence that investor location matters, in that mutual fund managers are better at picking stocks of firms that are close to where they are than stocks of firms from a more distant location.

Though foreign investors may be more sophisticated, they may lose out to domestic investors who have private information when they trade. This private information is likely to be more important in countries where insider trading is more likely to occur. Consequently, if foreign investors are more sophisticated, they might perform better in countries with limited insider trading but not those where insider trading is more prevalent. If residence enables investors to have access to private information, one would expect the value of this private information to be short-lived since the trading of investors will incorporate it into prices. Consequently, looking at the investment performance of foreign investors versus domestic investors over longer periods of time will make it difficult to assess the importance of such private information. Further, since stocks sold by foreign investors must be bought by domestic investors, it follows that if foreign investors have a particular investment style, then domestic investors as a group must have the opposite one. A number of papers show that foreign investors are momentum traders that have a preference for larger firms. The difficulties involved in controlling for style differences make it easy to attribute to the residence of investors differences in performance that are due instead to differences in style. These difficulties are compounded by the fact that existing studies often have short sample periods and few stocks. Performance differences between foreign investors and domestic investors are 
therefore unlikely to resolve the issue of whether domestic investors have private information advantages over foreign investors, especially if, as one would expect, these advantages are short-lived. In this paper, we use a high frequency database that allows us to investigate directly whether domestic investors have a private information advantage over foreign investors in a market where the policing of insider trading is generally considered to be weak.

Throughout the paper, we compare foreign investors to both domestic institutional investors and domestic individuals. Such a comparison is important for two reasons. First, foreign investors are mostly institutional investors. Consequently, we have to understand whether foreign investors differ from domestic investors as a group because they are foreign or simply because they are institutional investors. Second, in emerging markets, local institutional investors are not as important as they are in developed markets and their actions may at times be affected by political considerations. Foreign investors could do well compared to domestic institutions simply because the local institutions are underdeveloped, do not have access to valuable information that some domestic individuals have access to, or may even be trading to fulfill political objectives.

We find first that foreign investors buy at significantly higher and sell at significantly lower prices than domestic individuals for medium and large trades. We turn next to a comparison of foreign institutions with domestic institutions. We find that foreign institutions are less at a disadvantage relative to domestic institutions than relative to domestic individuals. Yet, for large trades, the disadvantage of foreign institutions seems to persist.

We then turn to an examination of trading by various investor classes around firm-specific news to evaluate whether domestic investors anticipate such news in their trading. One approach to proxy for firmspecific news would be to look at firm announcements. Seasholes (2000) analyzes trading ahead of earnings announcements. This approach is ideally suited to investigating whether foreign institutional investors have a better ability to analyze a firm's financial situation, which is what he is wants to understand. We study instead whether domestic investors have better access to short-lived private information than foreign investors. As such short-lived information gets incorporated into prices, it will 
lead to large absolute value abnormal returns if it is important. We therefore consider all events with large absolute value abnormal returns and investigate whether there are differences in the trading of domestic and foreign investors immediately around such events. We focus on such events rather than firm announcements since insider-trading enforcement is lax outside the United States. ${ }^{4}$ Consequently, by the time a public announcement is made, most of its content may already have been incorporated in the stock price. We would therefore miss the most important firm-specific information events by focusing on public announcements. $^{5}$

Strikingly, foreign investors are significant net buyers before a negative abnormal return event and significant net sellers before a positive abnormal return event. On event days, the net purchases of foreign investors are positive but insignificant if the abnormal return is positive and significantly negative if the abnormal return is negative. Foreign investors buy after a positive abnormal return and sell after a negative abnormal return. From this evidence, it is clear that foreign investors do not trade ahead of the event day on private information, but the trading of domestic investors is consistent with the hypothesis that they do so. We also find that during the days of large absolute value abnormal returns, foreign investors trade at worse prices than domestic individuals typically do.

The market can tell us whether foreign investors have information that domestic investors do not have. If foreign investors are better informed, trades by foreign investors should have a larger price impact than similar trades by domestic investors if the market can figure out whether trades are made by foreign investors or by domestic investors. We therefore compare the price impact of large matched trades by domestic institutions and foreign institutions using intraday data and daily data. The intraday analysis shows that there is no significant difference in the price impact of large trades between domestic and foreign institutions. We find, however, that large trades by domestic individual investors have both a larger immediate price impact and a larger permanent price impact.

\footnotetext{
${ }^{4}$ See Bhattacharya and Daouk (1999).

${ }^{5}$ See Bhattacharya, Daouk, Jorgenson, and Kehr (2000). In Seasholes (2000), earnings announcements have an announcement effect, so that not all of the information is incorporated in stock prices ahead of time.
} 
We then turn to an analysis of days with large buying or selling by an investor class. Using marketadjusted returns, the permanent price impact measured over 10 days is insignificant for trades by foreign institutions whether they buy or sell. The permanent price impact of domestic institutions is significant, but has the wrong sign for informed trading whether they buy or sell. In contrast, the permanent price impact of domestic individuals is consistent with them having private information. If purchases and sales take place at the last trade of the day, domestic individuals gain from buying and from selling. Foreign investors lose following purchases and domestic institutions lose following purchases or sales. Finally, on the day after large foreign buying, the market knows that foreign buying took place. Hence, if the market could not infer that large foreign buying took place the same day, the information would be impounded in stock prices the next day. A stock experiences a negative abnormal return the day after large buying by foreign investors and a positive abnormal return the day after large selling by foreign investors. This evidence is inconsistent with the view that investors believe that it is profitable for them to imitate trading by foreign investors.

The paper proceeds as follows. In Section 2, we introduce our data. In Section 3, we compare the prices at which various investor classes trade. In Section 4, we examine trading by various investor classes before large firm-specific price changes. In Section 5, we compare the price impact and the performance of trades for domestic and foreign investors. We conclude in Section 6.

\section{The Korea Stock Exchange and sample construction.}

During our sample period, the Korea Stock Exchange (KSE) holds two trading sessions on each weekday: a morning session and an afternoon session. Batch auctions are used three times a day to determine the opening prices of each session and the daily closing prices. There are no trades during the last 10 minutes of each day, when orders are collected for the closing batch auction. Trading prices during the rest of the trading hours are determined by continuous (or non-batch) auction. On Saturdays, there is only a morning session and the closing prices are determined by the batch auction. The KSE does not have 
designated market makers. Buyers and sellers meet via the Automated Trading System (ATS). Before November 25, 1996, only limit orders were allowed, but since then markets orders are allowed as well.

The database we use includes all transactions on the KSE for the period from November 25, 1996 to November 30, 1998, which is compiled by the Institute of Finance and Banking (IFB) at Seoul National University. This database has each order time-stamped as of the time that it arrives at the exchange and as of the time that the order is executed. The data provides information on the country of residence of investors as well as on whether they are individuals or institutions. Institutions are further classified into various types of institutions such as security firms, mutual funds, banks, and insurance companies. Foreign investors in Korea have to register with the Financial Supervisory Service (FSS) and obtain an ID number before they can start trading stocks. Through this ID number, the FSS makes sure that the foreign ownership limit for each company and each foreign investor is not exceeded by informing the KSE whether a foreign order satisfies the company and investor limits. The ownership limit for each individual foreign investor was $5 \%$ of a firm's shares until May 2, 1997, when it increased to 6\%. It then increased to $7 \%$ on November 3, and to $50 \%$ on December 11, 1997. In addition, foreign investors as a group could not own more than $20 \%$ of a firm's shares. This aggregate ownership limit on foreign investors increased to $23 \%$ on May 2, 1997, to $26 \%$ on November 3, 1997, and finally to $50 \%$ on December 11 , 1997 . One limitation of the foreign ownership database is that it is possible that trades we identify as foreign trades are actually trades by Korean investors who set up a foreign nominee company to trade on the KSE.

For both domestic and non-resident foreign investors (foreign investors), we generally report results for three investor classes: (1) individual investors, (2) securities firms, mutual funds, and pension funds (money managers), and (3) banks, insurance companies, and merchant banks (banks). We do not report results for resident foreign investors because their economic importance is trivial. We also ignore government and corporate holdings.

We have detailed ownership information for 1998. At the end of 1998, foreign investors owned $18 \%$ of the capitalization of Korean stocks. Domestic banks owned $7.30 \%$ of the Korean stock market, while domestic money managers owned $6.30 \%$. These numbers show that the domestic institutional investors 
owned a smaller fraction of the Korean stock market than foreign investors. Corporations owned $19.8 \%$ of the market, while the government and government-owned firms owned $19.70 \%$ of the market. Finally, individuals owned $28.90 \%$ of the market. Compared to Western countries, few individuals owned stocks directly since only $4.1 \%$ of Korean residents were investors in the market.

Most of the trading in the Korean stock market is due to individual investors. In 1998, $77.43 \%$ of the gross value of stock sales was by domestic individual investors. In contrast, $5.9 \%$ of the gross value of stock sales was by foreign investors and $13.71 \%$ was by domestic institutional investors. The gross stock sales by the government and by corporations together represented only $2.88 \%$ of the gross stock sales. The fact that the trading of the government and of the corporations represents such a small fraction of the overall trading explains why we do not focus on it in our study. With this data, domestic investors are more active traders than foreign investors and domestic individuals are more active traders than domestic institutions. Foreign investors sell stocks for a gross amount equal to $47 \%$ of their end-of-year ownership, while domestic individual investors sell stocks for a gross amount equal to $381 \%$ of their end-of-year ownership. Domestic institutions sell stocks for a gross amount of $143 \%$ of the value of their end-of-year holdings. Foreign investors are mostly institutions, but it follows from this that foreign institutions trade much less in Korea than domestic institutions.

Over our sample period there are three Korean ADRs trading on the NYSE in addition to the Korea Fund. At the end of 1996, the shares corresponding to the ADRs represent a small fraction of the outstanding shares of the firms that have issued ADRs (2.3\% for Kepco, 5.2\% for Posco, and 1.8\% for SK Telecom). Our data excludes New York trading. At most, New York trading affects the results for three stocks. It therefore cannot have a significant impact on our results that rely on all eligible stocks out of a possible 785 stocks. It would be interesting to investigate, however, whether the price impact of New York trades is different from the price impact of trades in Korea.

For the batch auctions, we cannot identify who initiates a trade. For the trades that do not take place during the batch auctions, we can use either all trades involving an investor class or only trades initiated by that investor class. We call a trade initiated by an investor class a price-setting trade by that investor 
class. For NYSE data, it is common to identify the initiating party of a trade using a tick test such as the one proposed by Lee and Ready (1991). There is no need for a tick test with our data because we know which party initiates the trade. A buy-side (sell-side) price-setting trade for foreign investors is a trade where the buy (sell) order of the foreign investors came after the sell-side (buy-side) order and hence made the trade possible. We consider split trades originated from one order as one trade irrespective of whether we consider all trades or only price-setting trades.

\section{Do foreign investors trade at worse prices?}

In this section, we investigate whether the various investor classes trade at different prices. We include in our sample all stock days where one of the investor classes investigated trades a stock. Define $P_{i}^{d t}$ as the price of stock $\mathrm{i}$ on day $\mathrm{d}$ for trade $\mathrm{t}$ and $V_{i}^{d t}$ as the size of the trade for stock $\mathrm{i}$ on day $\mathrm{d}$ for trade $\mathrm{t}$. We first compute the volume-weighted average price at which the stock traded using all trades that day:

$$
A_{i}^{d t}=\frac{\sum_{t} P_{i}^{d t} V_{i}^{d t}}{\sum_{t} V_{i}^{d t}}
$$

We then compute the volume-weighted average price for all trades involving the investor class we are interested in:

$$
B_{i, j}^{d t}=\frac{\sum_{t} P_{i, j}^{d t} V_{i, j}^{d t}}{\sum_{t} V_{i, j}^{d t}}
$$

where the subscript $\mathrm{j}$ denotes the investor class $\mathrm{j}$. We finally compute the ratio of the average price for all trades involving an investor class to all trades for a stock on a given day. The averages are calculated separately for purchases and sales. The equally weighted average of these ratios across days and stocks for each investor class is shown in Panel A of Table 1 for purchases for each investor class. In other words, for foreign money managers, the ratio gives us the equally weighted average across days and stocks of the volume-weighted average price at which they bought stocks normalized by the volumeweighted average price at which the stocks traded on the day they bought them. The results are reported 
for each investor class in three trade sizes. The trade sizes are constructed by dividing all trades in a stock on a day that it is in the sample into three groups.

Looking at the foreign money managers in Panel A of Table 1, we see that the ratio is 0.99887 for the smallest size trades, 1.00058 for the middle size trades, and 1.00048 for the largest size trades. All these numbers are significantly different from one. The question we are interested in, though, is whether these numbers differ from those for domestic investor classes. To address this question, we compare prices paid across investor classes $\mathrm{i}$ and $\mathrm{j}$ as follows. For each day on which both investor classes buy, we average the price paid by investor class $\mathrm{i}$ for trades in a size category and do the same for investor class $\mathrm{j}$. We then take the difference on that day between the price paid by investor class $\mathrm{i}$ and investor class $\mathrm{j}$. If one of the two investor classes does not trade on that day, we skip the day. We then report the t-statistic for the daily differences. With this approach, the difference between the price paid by investor class $i$ and the price paid by investor class $\mathrm{j}$ uses only days where both investor classes trade in a stock. As a result, it could be that the average price for investor class $i$ is higher than the average price for investor class $j$, yet the difference in prices paid by investor classes $\mathrm{i}$ and $\mathrm{j}$ is negative because the difference in prices paid ignores days when one of the classes does not trade. Both foreign money managers and foreign banks pay more than domestic individuals when we look across all trades. Across trade sizes, foreign money managers and banks pay more for large and medium trades than domestic individuals, but not for small trades. Compared to domestic institutions, the prices that foreign money managers pay are not significantly higher when we look across all trades. Foreign money managers buy at even lower prices than domestic money managers. However, foreign money managers pay more for large trades than domestic money managers or banks and pay less for small trades. When we turn to the foreign banks, we find that foreign banks buy at lower prices than domestic banks for small trades but buy at higher prices for medium trades. The comparison for large trades is not significant.

In Panel B of Table 1, we weight the ratios by the value of trades rather than equally. With this procedure, it is still the case that foreign investors buy at higher prices for large trades, but they no longer buy at higher prices for medium trades or for small trades. When we look at the ratios across all trades, 
foreign money managers do not buy at significantly higher prices than domestic individuals or domestic institutions. The same applies to foreign banks. These results indicate that the disadvantage of foreign investors is larger for smaller firms. This might provide part of the explanation for why foreign investors hold larger stocks as shown in Choe, Kho, and Stulz (1999) for Korea.

Panels C and D of Table 1 consider the prices at which investor classes sell stocks. Looking at all trades, foreign money managers and foreign banks sell at significantly lower prices than domestic individuals and domestic banks, but they sell at significantly higher prices than domestic money managers. For large trades, both foreign money managers and foreign banks sell at significantly lower prices than domestic individuals, money managers, and banks. For small trades, foreign investors either do better or not significantly worse than domestic investors. In particular, foreign money managers sell at higher prices than domestic individuals and domestic money managers. Strikingly, for foreign money managers, the average buy price exceeds the average sell price for medium and large trades, but is lower than the average sell price for small trades. However, in contrast, domestic individuals always sell at higher prices than they buy and domestic money managers always sell at lower prices than they buy. When we turn to tradeweighted averages in Panel D, domestic investors uniformly sell at higher prices than foreign investors. Looking at trade sizes, foreign investors sell at lower prices for large trades but not for small trades.

We can use Table 1 to assess the economic significance of the disadvantage of foreign investors relative to domestic individual investors. We use the equally weighted results. The foreign money managers typically pay $0.144 \%$ more than domestic individuals when they buy the stock and receive $0.162 \%$ less when they sell. The round-trip difference between foreign investors and domestic individuals is therefore about $0.306 \%$. Suppose a foreign investor buys a stock and holds it for one year. The performance of the foreign investor will therefore be about $0.306 \%$ less than the performance of a domestic individual who holds the same stock. This disadvantage is small in economic terms, so that it can lead to only a very small home bias. At the same time, however, this disadvantage would be a more serious deterrent for active traders. An active foreign investor who turns his portfolio over 10 times a year would underperform a domestic individual trading the same stocks on the same days by 306 basis points! 
Table 1 reports results that include the batch auctions that start each trading sessions with one price. Foreign investors choose when they want their trades to take place. Table 2 shows how trading is divided up during the day among our investor classes. Foreign investors trade fairly uniformly during the day. However, because domestic investors trade more during the morning, foreigners are more important as a proportion of trading volume in the afternoon than in the morning. If we examine the performance of foreign investors during the period when trading takes place continuously, we find results that are mostly similar to those we find in Table 1 where we include the batch sessions and the after-hour trading.

\section{Do some investor classes anticipate events better?}

In this section, we investigate whether some investor type has a greater ability to trade to benefit from large abnormal returns. For this investigation, we construct an event study of trading patterns of investor classes around days where stock prices have an abnormal return of at least $5 \%$ in absolute value. The abnormal return is defined as the residual of a market model regression over our sample period. The threshold for abnormal returns is arbitrary, but it should allow us to capture important events for the firms in our sample. Figure 1 shows that the observations are spread over the whole sample period. We examine the buy and sell proportions for the eleven days surrounding the day with the large abnormal return. We treat as missing observations the days when a stock has a price less than 1,000 won. Our sample includes all days where the price limit came into effect. Since trading can still occur at the limit price when the price limit is hit, there is no reason to suspect that the price limit affects our results since we focus on fractions of total trade on the days considered. In our analysis, we consider the eleven days around abnormal returns that exceed 5\% in absolute value. If two events have overlapping eleven-day event periods, we only use the eleven-day event period of the first event and do not use the eleven-day period of the second event to avoid using the same daily returns more than once in our sample. The analysis with overlapping intervals leads to similar conclusions.

In Table 3, we first examine how the proportion of buys and sells of the various investor classes changes around days with large positive abnormal returns. This allows us to look separately at buys and 
sells and to understand the relative importance of the various investor classes for buy and sell orders. We could average our observations across all event days or average observations within calendar days and then average across calendar days. It turns out that both approaches lead to similar conclusions. We report results for calendar days for two reasons. First, this approach does not make the assumption that trading within calendar days across observations is independent. Second, by weighting each calendar day equally, we do not give undue importance to days with a larger number of high absolute value abnormal returns.

Domestic individual investors dominate the trading on the days we report as they do with the data we reported for 1998 in Section 2. They have in excess of 75\% of the buy orders and of the sell orders on the days we report. Domestic institutions are much less important. Foreign investors are less important than either domestic individuals or domestic institutions except for the event days where foreign investors have more buy trades than domestic institutions. The increase in foreign buy trades on the event day is striking since the proportion of buy trades by foreign investors on the event day is more than twice its average over the five previous days. This increase in buy orders raises the concern that the abnormal return is somehow caused by foreign buy orders. The fraction of buy orders of domestic money managers does not change much on the day of the event. Not surprisingly therefore, domestic individuals see their fraction of buy orders drop.

If an investor class has private information about the event, we would expect that investor class to have a higher proportion of buys before the event than after and a lower proportion of sales before the event than after. The only investor class that exhibits such a trading pattern is the domestic individual investor class. The domestic individual investors buy (sell) significantly more (less) during the five days that precede the event than during the five days after the event. Their fraction of buy orders increases monotonically during these five days while their fraction of sell orders falls monotonically. Korean money managers buy insignificantly less before the event than after and sell significantly more before than after. Their buying falls and their selling increases before the event. Korean banks buy insignificantly more before than after and sell insignificantly less before than after. Finally, turning to foreign investors, we see that they buy significantly more after the event than before and sell significantly less after the event than 
before. While both domestic and foreign money managers increase their buying and decrease their selling after the event, the change is proportionately larger for foreign investors.

Since investors in an investor class generally both buy and sell a stock on the same day, we consider in Table 4 the change in ownership of shares for the various investor classes. Panel A of Table 4 shows the net change in the ownership fraction of the various investor classes before and after the event day with large positive abnormal returns for the whole sample. It also provides the net change in total foreign ownership. To compute the net change in the ownership fraction of an investor class, we first compute the change in ownership for that class for a day. We then average observations across stocks for the day and then across days. Panel A of Table 4 shows that foreign investors are significant net sellers before a day with a large positive abnormal return and insignificant net buyers afterwards. On the day of the event, foreign investors are insignificant buyers, making it difficult to believe that somehow they are causing the price increase. The causal role of foreign investors is even harder to fathom when we see that the net buying of domestic individual investors is more than forty times the net buying of foreign investors. The foreign investors sell to individuals before the event and buy from domestic institutions afterwards. Before the event, all institutional investor classes sell, regardless of whether they are domestic or foreign. After the event, domestic institutional investors keep selling, but foreign investors do not. On the day of the event, domestic individuals are significant buyers and they buy from domestic institutions. Foreign investors are not significant buyers on the event day. This evidence is consistent with an information advantage on the part of domestic individual investors and suggests that there is little difference between domestic and foreign institutional investors.

A concern about the results in Tables 3 and 4 is whether some foreign investors might actually be domestic investors. Because of tax advantages, it might make sense for Korean investors to trade using a Malaysian company. We therefore investigated whether our results differ if we exclude foreign investors from Malaysia. Investors from Malaysia seem to behave more like domestic investors. As a result, excluding these investors reinforces our conclusions rather than weakens them. 
Another approach to investigating whether foreign investors are informationally disadvantaged is to look at whether they pay higher prices on days of large positive abnormal returns than domestic investors. A necessary condition for an information disadvantage of foreign investors is that they buy at a higher price than domestic investors when private information is revealed during the day. We find that foreign investors pay more on days of large positive abnormal returns. From Table 1, we know that foreign investors pay more on average than domestic individuals when they buy by $0.144 \%$. However, when we look at days with abnormal returns in excess of $5 \%$, foreign investors pay more than domestic individuals by $0.53 \%$. The result that foreign investors trade at higher prices during event days is necessary to show that they have an information disadvantage, but it is not sufficient because we could find the same result if foreign investors were driving up the stock price because of large purchases. However, if foreign investors were driving prices up and did not have an information disadvantage, we would expect them to profit from their purchases. As we will see in the next section, this is not the case - at least in the short run.

We now turn to the results for days with abnormal returns below $-5 \%$. To save space, we do not reproduce results for Table 3 for these days. The results are fully consistent with the inferences we draw from Table 3. Individual investors buy slightly less before a large negative abnormal return than afterwards, while institutional and foreign investors buy more. Individual investors sell more before the event than afterwards while foreign investors sell less before the event than afterwards. Panel B of Table 4 shows the change in the ownership proportion of the various investor classes around days with a large negative abnormal return. Clear evidence of an information advantage for an investor class would be if the investors of that class decreased their ownership before the event. Foreign investors clearly do not have such an information advantage. They significantly increase their ownership for the five days before the event day and they significantly decrease their ownership afterwards. As a result, domestic investors sell to foreign investors before a large negative abnormal return in a stock. However, the selling of domestic investors is due to domestic institutional investors since domestic individual investors are net buyers. On the day of the large negative abnormal return, foreign investors sell to individuals and so do domestic 
institutional investors. However, the selling of foreign investors is smaller than the selling of institutions, so that again it is hard to argue that foreigners are somehow responsible for the adverse stock return.

With our tests, we did not condition on foreign ownership. However, for foreign investors to sell, they must own the stock since they cannot sell short. We therefore split our sample of large positive abnormal return events according to foreign ownership. Not surprisingly, the effect we document is magnified when we focus on stocks with larger foreign ownership. We split our sample of large negative abnormal return events in the same way, but for these events, as one would expect, conditioning on foreign ownership is not important.

We investigated but do not report in a table whether the effects we document are more prevalent in large or small stocks. A priori, it is not clear what we should expect. Foreign investors invest less in small stocks, so that it would be harder to take advantage of them in such stocks. Further, these stocks will be less liquid, so that less trading takes place. At the same time, however, since small stocks are followed less by analysts, private information is more likely to be important for such stocks. The effects we document are significant for small and large stocks for positive abnormal returns, but are significant only for large stocks for negative abnormal returns.

Our evidence shows that domestic investors buy from foreign investors before large positive abnormal returns and sell to them before large negative abnormal returns. This implies that there is statistical evidence of an information advantage of domestic investors. To evaluate the economic significance of this information advantage, we have to remember that, since we choose events with large abnormal returns, the informed trading before the event has to be sufficiently limited that its effect on prices is small enough for us to still have an event to examine. Despite this qualification, the informed trading seems small when compared to shares outstanding. The net accumulation (selling) of shares by domestic investors during the five days that precede a large positive (negative) abnormal return is less than one percent of shares outstanding in absolute value. The extent to which investors can accumulate shares depends on the trading volume. If a stock has a large trading volume relative to the number of shares outstanding, an investor type is more likely to be able to change its ownership significantly over a few days. This suggests that to 
evaluate the importance of the information advantage we discuss, it makes sense to also look at trading by investor classes normalized by volume. Though we do not report trading normalized by volume in tables, domestic investors buy from foreign investors about one percent of volume during the five days before a positive abnormal return day, but they sell $11.5 \%$ of volume during the five days before a negative abnormal return. Domestic investors can only buy from foreign investors if foreign investors own the stock and sell to foreign investors if these investors follow the stock and are trading in it. Consequently, one would expect that domestic investors would benefit more from their private information at the expense of foreign investors for stocks with high foreign ownership. The ability of domestic investors to take advantage of their private information will also be affected by volume. If we look at the day before the abnormal return, we find that the net buying of domestic investors is $2.14 \%$ of volume for stocks with large foreign ownership before a positive abnormal return and the net selling of domestic investors is $3.84 \%$ of volume before a negative abnormal return.

\section{The price impact and performance of intensive buying and selling by investor classes.}

In this section, we compare the price impact and the performance of trades of different investor classes. We conduct two studies where we examine the impact of large order imbalances by investor classes. The first study focuses on intervals of five minutes. The second study uses daily data. With the daily data, investors know the next day that an investor class was very active. In both studies, we use only price-setting trades by the investor class to take into account the fact that trades that investors want executed immediately are more likely to be information-motivated. Throughout the two studies, we use stocks for which we have at least 300 days with trading on the day and on the previous day. Further, we eliminate all stocks whose price falls below 1,000 won during the sample period. We end up with a sample of 512 stocks out of a possible 785 stocks. 


\section{A. Intra-day study.}

We divide each week day into 47 five-minute intervals from 9:30 a.m. to 15:00 p.m., treating the time interval of 11:30 a.m. to 13:05 p.m. as a single interval containing the lunch break and similarly for the time interval of 14:50 a.m. 15:00 p.m. containing an order collection period for the close. For Saturdays, we have 23 five-minute periods. We look at returns for the 10 five-minute periods preceding the event and the 10 subsequent five-minute periods. We allow the sequence of five-minute periods to cross day boundaries. For each of the intervals for each of the 512 stocks over the sample period, we compute pricesetting order imbalances by an investor type by subtracting the price-setting sell volume from the pricesetting buy volume. We then select the 10 intervals for net buy (positive) price-setting imbalances and 10 intervals for net sell (negative) price-setting imbalances for each investor type. For each of the selected events, we examine stock returns from the previous tenth $(-10)$ to the subsequent tenth $(+10)$ interval surrounding the event. We report raw stock returns as well as returns minus the sample average for the matching time interval.

We first consider the largest price-setting imbalances by foreign investors in Panel A of Table 5. For net buy imbalances, we see a strong positive abnormal return during the interval of the price setting imbalance. We compute mean-adjusted returns by subtracting from the return for a given interval the sample average return for that interval on that day of the week. Looking at mean-adjusted returns, we see that during the interval D0, the stock has a positive return of $1.041 \%$ with a t-statistic of 30.25 . The next interval is still positive, but it is followed by a string of negative returns. Foreign investors have the largest price-setting order imbalances following positive mean adjusted returns. The cumulative return from interval D0 to D+10 is $0.897 \%$. However, from interval D+1 to D+10, the cumulative mean-adjusted return is $-0.144 \%$. If the period of intensive trading leads to a greater price increase than the price increase in the long-run resulting from the information conveyed by the intensive trading, perhaps because a compensation is required for liquidity providers, one can expect the excess in the price increase to disappear over the next few periods. Consequently, we measure the permanent effect of the intensive trading by the cumulative abnormal return from the end of the period immediately preceding the intensive 
trading to 10 periods after the intensive trading period, $\mathrm{CAR}(0,+10)$. If stock prices adjust completely to the new information over the 10 periods following the intensive trading period, the cumulative abnormal return from interval +1 to interval +10 offsets the transitory part of the return associated with the intensive trading period. Following Holthausen, Mayers, and Leftwich $(1987)$, we call CAR $(+1,+10)$ the temporary price effect. Panel A of Table 5 shows that the permanent effect of the intensive buying by foreign investors is larger than the temporary effect. When we turn to price-setting sales, we find a mean-adjusted return of $-0.730 \%$ at D0. The permanent effect is only $-0.136 \%$ with a t-statistic of -2.97 .

The question we are interested in is how the price impact of the foreign investor trades compares to the price impact of domestic investor trades. Panel B of Table 5 shows that purchases by domestic institutions have a higher price impact. The D0 mean-adjusted return for institutions is $1.220 \%$ which is $0.179 \%$ more than for foreign investors. The permanent impact is $0.950 \%$, which exceeds the price impact of trades by foreign investors by $0.053 \%$. Looking at sell trades by domestic institutions, we find that the price impact at D0 is higher in absolute value since it is -0.933 compared to -0.730 for foreign investors, but the permanent impact is actually less for domestic institutions since it is $-0.085 \%$ compared to $0.136 \%$ for foreign institutions. Based on this evidence, one has to conclude that the differences in price impact between domestic and foreign institutional investors are small. A legitimate question, however, is whether our evidence could be obscured by differences in trade sizes. To address this question, we looked at matched trades in Panel $\mathrm{C}$ of Table 5. There, we find that we cannot reject that the permanent price impact of trades is the same for domestic and foreign institutions. However, the immediate impact of trades is bigger for domestic institutions than for foreign institutions.

Panel D of Table 5 provides evidence for domestic individual investors. We see that the immediate price impact of trades by domestic individuals is similar to the one of institutions, but the permanent priceimpact is higher. The price impact of sell trades is again comparable to the one of institutions, but the permanent price impact is higher. For individual trades, the permanent price impact for sell trades is $0.456 \%$, while for institutions it is $-0.085 \%$. In other words, the permanent price impact of individual investors is consistent with them being better informed than either domestic or foreign institutions. 
Though not reported, it is striking that the relative size of the price-setting imbalances for our events of domestic institutions and foreign investors are roughly of the same size. For instance, the price-setting buy imbalance of foreign investors at D0 is $20.72 \%$ relative to the total trade volume of the day, while the price setting buy imbalance of domestic institutions is $20.27 \%$. In contrast, the price setting buy imbalance of individuals is a much smaller $6.28 \%$. In other words, individuals have a large permanent price impact out of trades that are less than a third the size of the trades of domestic or foreign institutions.

We conducted the same study for a sample that includes all order imbalances. These results confirm that focusing on price-setting orders amounts to focusing on the orders that are information-motivated. For foreign investors, the buy order imbalances lead to similar but slightly dampened results, but the sell-order imbalances are associated with a positive permanent price effect. The same outcome holds for domestic institutions. Finally, for domestic individuals, the results are paradoxical. A buy imbalance by domestic individuals is associated with a negative mean-adjusted return of $-0.777 \%$, but the permanent effect is $0.172 \%$ with a t-statistic of 3.37 . A sell imbalance by domestic investors is associated with a D0 meanadjusted return of $1.478 \%$ for a permanent price impact of $0.775 \%$.

\section{B. Inter-day study.}

We now investigate the impact of large daily order-imbalances. Our sample includes the 10 days with the highest net buy and net sell imbalances for each stock. The interest of looking at daily orderimbalances is two-fold. First, investors know on the day following the imbalance that an investor type had a large order imbalance the previous day. Consequently, if investors believe that the investor class with the large order imbalance had private information but that private information was only partially incorporated into prices because the market did not know that the investor class had a large order imbalance, we should see a continuation the next day. Second, if investors trade on information that gets revealed within the next few days, we can answer the question of whether they made profits on their trades. Investors learn the aggregate net buying of foreign investors in a stock rather than the net-buy price-setting imbalance. Consequently, we use the net-buy and net-sell imbalances in our daily analysis. 
We first consider the impact of the net-buy and net-sell imbalances of foreign investors. We report raw returns, mean-adjusted returns, and market-adjusted returns, which are excess returns over the KOSPI index. We focus our discussion on the market-adjusted returns. Panel A of Table 6 shows that the net-buy imbalances have a significant impact on D0. There is no continuation, so that no case can be made that the market gets valuable information from knowing that foreign investors were active on the previous day. For purchases by foreign investors, the next day abnormal return is insignificantly negative. For sales by foreign investors, the next day has a significant positive abnormal return which is of the same order of magnitude as the negative abnormal return on the day of the net-sell imbalance. If we compute cumulative abnormal returns from the day before the foreign net-buy and net-sell imbalances, these imbalances are not associated with significant abnormal returns. This means that the net-buy and net-sell imbalances have no permanent price impact. However, if the foreign investors buy at the end of the trading day, they experience a significant negative cumulative abnormal return over the ten days following the trade. No case can be made, therefore, that the foreign investors have valuable information that leads them to profit from large purchases. Following a net-sell imbalance, the cumulative abnormal return from day 1 to day 10 is insignificant.

Domestic institutions shown in Panel B of Table 6 have a positive price impact through their buy trades also. However, domestic institutions buy ahead of significantly poor performance of a stock, so that the net permanent effect is negative. When domestic institutions sell, the market-adjusted abnormal return is positive. The selling by domestic institutions is good news in that the permanent effect of large sell days by institutions is positive and significant. Hence, whether domestic institutions have a net buy imbalance or a net sell imbalance, these imbalances affect stock prices in the opposite direction from the one we would expect if they had valuable information and they lose on their purchases or sales. The price impact of domestic institutions is smaller than the price impact of foreign institutions for purchases. However, the size of the order-imbalances of domestic and foreign institutions are not the same, so that the difference in price impact may be the result of different order-imbalance sizes. Panel $\mathrm{C}$ of Table 6 uses a matched sample of imbalances for domestic and foreign institutions. It is clear there that foreign institutions have a 
significantly higher price impact. However, the permanent price impact of foreign institutions is not signficantly positive. The stock price falls more following purchases by domestic institutions than by foreign institutions. When we look at sales, the net-sell imbalances of foreign institutions have a negative price impact the same day while the net-sell imbalances of domestic institutions is positive. The difference between the two imbalances is significant. After 10 days, the stock price is higher following sales by domestic institutions than sales by foreign institutions. Domestic institutions net-sale order-imbalances are associated with a positive permanent price impact. This surprising impact of net-sale order-imbalances by domestic institutions suggests that these institutions may be mostly attempting to sell stocks when the market for these stocks can withstand their sales. As a result, they end up selling on days where stocks have positive returns. It could well be that this behavior might have been exacerbated by political pressures that might have made domestic institutions reluctant to be seen as driving prices down through large sales.

We finally turn to individuals in Panel D of Table 6. The large net-buy imbalance events for individuals have a positive price impact on D0 and a continuation the next day. The net-buy imbalances of domestic individuals have a significant positive permanent effect on the stock price. Further, domestic individuals make a gain from their purchases over the ten days following the purchases. The price impact of net-sell imbalances is surprisingly positive. However, the market-adjusted return is negative every day for the 10 days following the sale. As a result, net-sell imbalances by domestic individuals have a negative permanent effect and individuals benefit from their sales in that, had they held on to the stock, they would have made losses.

Table 6 shows that institutions, whether domestic or foreign, do not seem to benefit from their purchases. If institutions purchase at the closing price on the event day, they make a significant negative abnormal return over the next 10 days. Looking at sales, domestic institutions make significant losses from the close of the event day to 10 days later but foreign institutions do not make significant losses. In contrast, domestic individuals benefit from their net-buy and net-sell imbalances. The evidence is 
therefore consistent with the results of the earlier sections showing that domestic individuals have valuable private information in contrast to institutions.

\section{Conclusion.}

In this paper, we used a number of different approaches to infer whether domestic investors have a private information advantage over foreign investors for individual stocks. We saw that foreign investors trade at worse prices, sell before large positive abnormal returns, buy before large negative abnormal returns, and finally do not gain from large trades for the first ten days following the trades. The private information disadvantage of foreign investors is relative to domestic individual investors. Foreign investors do not seem disadvantaged relative to domestic institutions, but this may be partly because domestic institutions were under stress during our sample period.

Though our results show that domestic individual investors have a private information advantage, they also imply that this private information advantage is unlikely to have much of an impact on the portfolio allocation of a buy-and-hold investor. A foreign investor who buys and sells on random days buys at a slightly higher price and sells at slightly lower price than domestic individual investors. However, these price differences are small enough that they would have only a minimal impact on the expected returns of investors who plan to hold stocks for a substantial period of time. Consequently, the private information advantage we document cannot explain why buy-and-hold investors would be reluctant to invest abroad to the extent that they do. However, we show that the private information advantage of domestic investors can represent a substantial disadvantage for active foreign investors. 


\section{References}

Bhattacharya, Utpal, and Hazem Daouk, 1999, The world price of insider trading, Working paper, Indiana University, Bloomington, Indiana.

Bhattacharya, U., H. Daouk, B. Jorgenson, and C. Kehr, 2000, When an event is not an event: The curious case of an emerging market, Journal of Financial Economics 55, 69-101.

Brennan, Michael J., and Cao, Henry H., 1997, International portfolio investment flows, Journal of Finance 52, 1851-1880.

Calvo, Guillermo A., and Enrique G. Mendoza, 2000, Rational contagion and the globalization of securities markets, Journal Of International Economics 51, 79-113.

Choe, Hyuk, Bong-Chan Kho, and René M. Stulz, 1999, Do foreign investors destabilize stock markets? The Korean experience in 1997, Journal of Financial Economics, 227-264.

Coval, Joshua D., and Tobias J. Moskowitz, 1999, Home bias at home: Local equity preference in domestic portfolios, Journal of Finance 54, 2045-2073.

French, Kenneth R., and James M. Poterba, 1991, Japanese and U.S. cross-border common stock investments, American Economic Review 81, 222-226.

Grinblatt, Mark, and Matti Keloharju, 2000, The investment behavior and performance of various investor types: a study of Finland's unique data set, Journal of Financial Economics 55, 43-67.

Hau, Harald, 2000, Location matters: An examination of trading profits, Journal of Finance, forthcoming.

Holthausen, Robert W., Richard W. Leftwich, and David Mayers, 1987, The effect of large block

transactions on security prices: A cross-sectional analysis, Journal of Financial Economics, 19, 237-268.

Kang, Jun-Koo, and René M. Stulz, 1997, Why is there a home bias? An analysis of foreign portfolio equity ownership in Japan, Journal of Financial Economics 46, 2-28.

Lee, Charles M. C., and Mark A. Ready, 1991, Inferring trade direction from intraday data, Journal of Finance 46, 733-746.

Seasholes, Mark, 2000, Smart foreign traders in emerging markets, Working Paper, Harvard Business School, Cambridge, MA.

Tesar, Linda L., and Ingrid M. Werner, 1995, Home bias and high turnover, Journal of International Money and Finance 14, 467-492. 
Table 1. Volume-weighted buy and sell prices of each investor type across stock-days with at least one foreign trade (12/2/96 11/30/98: 586 days) For each stock $i$ and day $d$ ( $t$ is the sequence of trades for the stock-day), the following values are calculated for each investor type $j$.

$$
A_{i}^{d}=\sum_{t} P_{i}^{d t} V_{i}^{d t} / \sum_{t} V_{i}^{d t}, B_{i, j}^{d}=\sum_{t} P_{i, j}^{d t} V_{i, j}^{d t} / \sum_{t} V_{i, j}^{d t}, \mathrm{H}_{0}: E\left(B_{i, j}^{d} / A_{i}^{d}\right)=1, \quad \forall j=(1), \ldots,(6) \text { under the null. }
$$

Panel A. Buy prices, equally weighted across stocks and then across days

\begin{tabular}{|c|c|c|c|c|c|c|c|c|c|c|c|c|c|c|c|c|c|c|}
\hline \multirow[b]{2}{*}{$\begin{array}{c}\text { All groups of daily trade- } \\
\text { value }\end{array}$} & \multicolumn{9}{|c|}{ Domestic investors } & \multicolumn{9}{|c|}{ Non-resident foreign investors } \\
\hline & \multicolumn{3}{|c|}{ (1) Individual } & \multicolumn{3}{|c|}{$\begin{array}{l}\text { (2) Securities, Mutual, } \\
\text { Pension funds }\end{array}$} & \multicolumn{3}{|c|}{$\begin{array}{l}\text { (3) Banks, Insurance, } \\
\text { Merchant banks }\end{array}$} & \multicolumn{3}{|c|}{ (4) Individual } & \multicolumn{3}{|c|}{$\begin{array}{l}\text { (5) Securities, Mutual, } \\
\text { Pension funds }\end{array}$} & \multicolumn{3}{|c|}{$\begin{array}{l}\text { (6) Banks, Insurance, } \\
\text { Merchant banks }\end{array}$} \\
\hline Avg. of median trade val $(000)$ & & 469,315 & & & 127,875 & & & 98,636 & & & 21,228 & & & 106,841 & & & 154,071 & \\
\hline Avg. of $A$ (in won) & & 23,644 & & & 27,009 & & & 26,821 & & & 20,897 & & & 28,166 & & & 33,101 & \\
\hline Average of Buy B/A & & 0.99882 & & & 1.00007 & & & 0.99950 & & & 1.00049 & & & 0.99983 & & & 0.99935 & \\
\hline$\left(\mathrm{t}\right.$-stat: $\left.\mathrm{H}_{0}=1\right)$ & & $(-24.98)$ & & & $(0.66)$ & & & $(-3.10)$ & & & $(1.18)$ & & & $(-1.65)$ & & & $(-2.61)$ & \\
\hline Avg. of Median & & 0.99997 & & & 1.00021 & & & 0.99975 & & & 1.00064 & & & 1.00004 & & & 0.99976 & \\
\hline Avg. of Std dev & & 0.00692 & & & 0.01252 & & & 0.01343 & & & 0.01532 & & & 0.01278 & & & 0.01092 & \\
\hline Avg \# of stocks per day & & 141.0 & & & 81.5 & & & 34.5 & & & 7.2 & & & 77.5 & & & 10.5 & \\
\hline Avg. of Sell $B / A-$ Buy $B / A$ & & 0.00225 & & & -0.00098 & & & 0.00228 & & & 0.00691 & & & -0.00041 & & & -0.00043 & \\
\hline (t-stat: $\left.\mathrm{H}_{0}=0\right)$ & & $(36.68)$ & & & $(-5.82)$ & & & $(6.20)$ & & & $(4.21)$ & & & $(-2.22)$ & & & $(-0.70)$ & \\
\hline Difference of Buy $B / A$ from (1) & & & & & -0.00136 & & & -0.00051 & & & -0.00112 & & & -0.00144 & & & -0.00062 & \\
\hline$\left(\mathrm{t}\right.$-stat: $\left.\mathrm{H}_{0}=0\right)$ & & & & & $(-9.87)$ & & & $(-2.63)$ & & & $(-2.65)$ & & & $(-10.16)$ & & & $(-2.06)$ & \\
\hline Difference of Buy $B / A$ from (2) & & & & & & & & 0.00049 & & & -0.00036 & & & 0.00028 & & & -0.00002 & \\
\hline (t-stat: $\mathrm{H}_{0}=0$ ) & & & & & & & & (2.28) & & & $(-0.60)$ & & & (1.78) & & & $(-0.07)$ & \\
\hline $\begin{array}{l}\text { Difference of Buy } B / A \text { from (3) } \\
\left.\text { (t-stat: } \mathrm{H}_{0}=0\right)\end{array}$ & & & & & & & & & & & $\begin{array}{r}-0.00136 \\
(-1.59)\end{array}$ & & & $\begin{array}{r}-0.00018 \\
(-0.70)\end{array}$ & & & $\begin{array}{r}-0.00037 \\
(-0.69)\end{array}$ & \\
\hline Difference of Buy $B / A$ from (4) & & & & & & & & & & & & & & 0.00006 & & & -0.00018 & \\
\hline (t-stat: $\mathrm{H}_{0}=0$ ) & & & & & & & & & & & & & & $(0.09)$ & & & $(-0.17)$ & \\
\hline $\begin{array}{l}\text { Difference of Buy } B / A \text { from (5) } \\
\left.\text { (t-stat: } \mathrm{H}_{0}=0\right)\end{array}$ & & & & & & & & & & & & & & & & & $\begin{array}{r}0.00018 \\
(0.64)\end{array}$ & \\
\hline By daily trade-value group & 1 & 2 & 3 & 1 & 2 & 3 & 1 & 2 & 3 & 1 & 2 & 3 & 1 & 2 & 3 & 1 & 2 & 3 \\
\hline Avg. of median trade val (000) & 37,372 & 200,1011 & $\overline{1,185,503}$ & 27,133 & 172,992 & 834,685 & 33,217 & 162,028 & 814,379 & 14,162 & 148,856 & 758,083 & 27,909 & 163,586 & 948,800 & 29,318 & 175,1871 & $\overline{1,104,860}$ \\
\hline Avg. of $A$ (in won) & 31,700 & 24,482 & 21,513 & 22,473 & 27,735 & 35,703 & 22,061 & 29,217 & 37,158 & 19,841 & 24,665 & 53,975 & 22,780 & 29,765 & 37,438 & 26,942 & 34,910 & 48,590 \\
\hline $\begin{array}{l}\text { Average of Buy } B / A \\
\left(\mathrm{t} \text {-stat: } \mathrm{H}_{0}=1\right)\end{array}$ & $\begin{array}{l}0.99589 \\
(-25.51)\end{array}$ & $\begin{array}{l}0.99878 \\
(-19.94)\end{array}$ & $\begin{array}{c}0.99976 \\
(-8.24)\end{array}$ & $\begin{array}{c}0.99992 \\
(-0.41)\end{array}$ & $\begin{array}{r}1.00012 \\
(1.05)\end{array}$ & $\begin{array}{r}0.99982 \\
(-1.71)\end{array}$ & $\begin{array}{c}0.99846 \\
(-5.88)\end{array}$ & $\begin{array}{r}1.00034 \\
(1.49)\end{array}$ & $\begin{array}{r}1.00008 \\
(0.32)\end{array}$ & $\begin{array}{r}1.00026 \\
(0.58)\end{array}$ & $\begin{array}{r}1.00186 \\
(2.01)\end{array}$ & $\begin{array}{r}0.99998 \\
(-0.01)\end{array}$ & $\begin{array}{r}0.99887 \\
(-6.51)\end{array}$ & $\begin{array}{r}1.00058 \\
(4.50)\end{array}$ & $\begin{array}{r}1.00048 \\
(4.43)\end{array}$ & $\begin{array}{r}0.99807 \\
(-4.04)\end{array}$ & $\begin{array}{c}0.99994 \\
(-0.18)\end{array}$ & $\begin{array}{r}1.00028 \\
(0.86)\end{array}$ \\
\hline Avg. of Median & 0.99905 & 0.99990 & 0.99999 & 1.00035 & 1.00018 & 0.99997 & 0.99858 & 1.00026 & 1.00021 & 1.00048 & 1.00193 & 1.00019 & 0.99947 & 1.00026 & 1.00025 & 0.99823 & 1.00012 & 1.00018 \\
\hline Avg. of Std dev & 0.01248 & 0.00590 & 0.00351 & 0.01526 & 0.01056 & 0.00754 & 0.01487 & 0.01162 & 0.00872 & 0.01547 & 0.01307 & 0.01377 & 0.01559 & 0.01031 & 0.00661 & 0.01321 & 0.00814 & 0.00548 \\
\hline Avg \# of stocks per day & 19.7 & 45.1 & 76.2 & 32.7 & 29.1 & 19.7 & 15.8 & 13.7 & 5.4 & 6.5 & 1.7 & 1.3 & 35.4 & 26.3 & 15.9 & 5.8 & 4.0 & 2.6 \\
\hline Avg. of Sell $B / A-$ Buy $B / A$ & 0.00522 & 0.00243 & 0.00126 & -0.00126 & -0.00075 & -0.00035 & 0.00263 & 0.00210 & 0.00184 & 0.00695 & 0.00562 & 0.00372 & 0.00197 & -0.00106 & -0.00156 & -0.00135 & 0.00027 & -0.00191 \\
\hline $\begin{array}{l}\left(\mathrm{t}-\mathrm{stat}: \mathrm{H}_{0}=0\right) \\
\text { Difference of Buy } B / A \text { from }(1)\end{array}$ & (25.92) & (28.36) & $(29.03)$ & $\begin{array}{r}(-4.57) \\
-0.00125\end{array}$ & $\begin{array}{r}(-3.61) \\
-0.00144\end{array}$ & $\begin{array}{r}(-1.92) \\
-90009\end{array}$ & $\begin{array}{r}(4.29) \\
0\end{array}$ & (3.89) & $\begin{array}{r}(3.60) \\
-0.00115\end{array}$ & $\begin{array}{r}(3.70) \\
-0.90084\end{array}$ & $(1.88)$ & $\begin{array}{r}(0.59) \\
-0.00176\end{array}$ & $\begin{array}{r}(5.03) \\
-0.00015\end{array}$ & $(-3.27)$ & $(-6.83)$ & $(-1.01)$ & $(0.30)$ & $\begin{array}{r}(-2.54) \\
-0.00216\end{array}$ \\
\hline $\begin{array}{l}\text { Difference of Buy } B / A \text { from (1) } \\
\left.\text { (t-stat: } \mathrm{H}_{0}=0\right)\end{array}$ & & & & $\begin{array}{r}-0.00125 \\
(-5.74)\end{array}$ & $\begin{array}{r}-0.00144 \\
(-8.45)\end{array}$ & $\begin{array}{r}-0.00098 \\
(-5.13)\end{array}$ & $\begin{array}{r}0.00051 \\
(1.75)\end{array}$ & $\begin{array}{r}-0.00127 \\
(-4.58)\end{array}$ & $\begin{array}{r}-0.00115 \\
(-3.03)\end{array}$ & $\begin{array}{r}-0.00084 \\
(-1.86)\end{array}$ & $\begin{array}{r}-0.00306 \\
(-2.77)\end{array}$ & $\begin{array}{r}-0.00176 \\
(-0.78)\end{array}$ & $\begin{array}{r}-0.00015 \\
(-0.71)\end{array}$ & $\begin{array}{r}-0.00250 \\
(-12.44)\end{array}$ & $\begin{array}{r}-0.00226 \\
(-11.47)\end{array}$ & $\begin{array}{r}0.00085 \\
(1.68)\end{array}$ & $\begin{array}{r}-0.00102 \\
(-2.49)\end{array}$ & $\begin{array}{r}-0.00216 \\
(-4.12)\end{array}$ \\
\hline $\begin{array}{l}\text { Difference of Buy } B / A \text { from (2) } \\
\left.\text { (t-stat: } \mathrm{H}_{0}=0\right)\end{array}$ & & & & & & & $\begin{array}{r}0.00238 \\
(6.76)\end{array}$ & $\begin{array}{r}-0.00075 \\
(-2.46)\end{array}$ & $\begin{array}{r}-0.00088 \\
(-2.12)\end{array}$ & $\begin{array}{r}-0.00007 \\
(-0.12)\end{array}$ & $\begin{array}{r}-0.00117 \\
(-0.73)\end{array}$ & $\begin{array}{r}-0.00089 \\
(-0.37)\end{array}$ & $\begin{array}{r}0.00254 \\
(9.06)\end{array}$ & $\begin{array}{r}-0.00054 \\
(-2.21)\end{array}$ & $\begin{array}{r}-0.00170 \\
(-7.09)\end{array}$ & $\begin{array}{r}0.00129 \\
(1.93)\end{array}$ & $\begin{array}{r}-0.00059 \\
(-1.22)\end{array}$ & $\begin{array}{r}-0.00175 \\
(-2.64)\end{array}$ \\
\hline Difference of Buy $B / A$ from (3) & & & & & & & & & & -0.00116 & -0.00350 & 0.00494 & 0.00230 & -0.00101 & -0.00164 & 0.00261 & -0.00183 & -0.00142 \\
\hline (t-stat: $\left.\mathrm{H}_{0}=0\right)$ & & & & & & & & & & $(-1.24)$ & $(-1.89)$ & $(0.79)$ & $(4.53)$ & $(-2.31)$ & $(-3.97)$ & $(2.65)$ & $(-2.47)$ & $(-1.43)$ \\
\hline $\begin{array}{l}\text { Difference of Buy } B / A \text { from (4) } \\
\text { (t-stat: } \mathrm{H}_{0}=0 \text { ) }\end{array}$ & & & & & & & & & & & & & 0.00270 & -0.00043 & -0.00059 & -0.00052 & 0.00039 & $\begin{array}{r}-0.00267 \\
(-1.65)\end{array}$ \\
\hline $\begin{array}{l}\left.\text { (t-stat: } \mathrm{H}_{0}=0\right) \\
\text { Difference of Buy } B / A \text { from (5) }\end{array}$ & & & & & & & & & & & & & & & & $\begin{array}{r}(-0.20) \\
0.00142\end{array}$ & 0.00022 & $\begin{array}{r}(-1.03) \\
-0.00078\end{array}$ \\
\hline$\left(\mathrm{t}\right.$-stat: $\left.\mathrm{H}_{0}=0\right)$ & & & & & & & & & & & & & & & & $(2.47)$ & $(0.58)$ & $(-1.84)$ \\
\hline
\end{tabular}


Table 1. (Continued)

Panel B. Buy prices, weighted by trade value across stocks and then across days

\begin{tabular}{|c|c|c|c|c|c|c|c|c|c|c|c|c|c|c|c|c|c|c|}
\hline \multirow[b]{2}{*}{$\begin{array}{l}\text { All groups of daily trade- } \\
\text { value }\end{array}$} & \multicolumn{9}{|c|}{ Domestic investors } & \multicolumn{9}{|c|}{ Non-resident foreign investors } \\
\hline & \multicolumn{3}{|c|}{ (1) Individual } & \multicolumn{3}{|c|}{$\begin{array}{l}\text { (2) Securities, Mutual, } \\
\text { Pension funds }\end{array}$} & \multicolumn{3}{|c|}{$\begin{array}{l}\text { (3) Banks, Insurance, } \\
\text { Merchant banks }\end{array}$} & \multicolumn{3}{|c|}{ (4) Individual } & \multicolumn{3}{|c|}{$\begin{array}{l}\text { (5) Securities, Mutual, } \\
\text { Pension funds }\end{array}$} & \multicolumn{3}{|c|}{$\begin{array}{l}\text { (6) Banks, Insurance, } \\
\text { Merchant banks }\end{array}$} \\
\hline$\overline{\text { Avg. of median trade val }(000)}$ & & 469,315 & & & 127,875 & & & 98,636 & & & 21,228 & & & 106,841 & & & 154,071 & \\
\hline Avg. of $A$ (in won) & & 27,605 & & & 29,203 & & & 30,530 & & & 27,024 & & & 30,079 & & & 34,099 & \\
\hline Average of Buy $B / A$ & & 0.99902 & & & 0.99901 & & & 0.99888 & & & 1.00025 & & & 0.99914 & & & 0.99902 & \\
\hline (t-stat: $\left.\mathrm{H}_{0}=1\right)$ & & $(-5.63)$ & & & $(-6.04)$ & & & $(-4.55)$ & & & $(0.47)$ & & & $(-3.70)$ & & & $(-2.80)$ & \\
\hline Avg. of Median & & 0.99997 & & & 1.00021 & & & 0.99975 & & & 1.00064 & & & 1.00004 & & & 0.99976 & \\
\hline Avg. of Std dev & & 7.77036 & & & 18.76593 & & & 25.30398 & & & 25.17246 & & & 17.63829 & & & 21.95100 & \\
\hline Avg \# of stocks per day & & 141.0 & & & 81.5 & & & 34.5 & & & 7.2 & & & 77.5 & & & 10.5 & \\
\hline Avg. of Sell $B / A-$ Buy $B / A$ & & 0.00189 & & & 0.00041 & & & 0.00273 & & & 0.00740 & & & -0.00035 & & & -0.00019 & \\
\hline Difference of Buy $B / A$ from (1) & & & & & 0.00001 & & & 0.00027 & & & -0.00085 & & & $\begin{array}{r}(-1.46) \\
-0.00028\end{array}$ & & & $\begin{array}{r}(-0.30) \\
-0.00032\end{array}$ & \\
\hline (t-stat: $\mathrm{H}_{0}=0$ ) & & & & & $(0.04)$ & & & $(0.87)$ & & & $(-1.54)$ & & & $(-1.48)$ & & & $(-0.93)$ & \\
\hline Difference of Buy $B / A$ from (2) & & & & & & & & 0.00025 & & & -0.00058 & & & -0.00040 & & & -0.00006 & \\
\hline$\left(\mathrm{t}\right.$-stat: $\left.\mathrm{H}_{0}=0\right)$ & & & & & & & & $(0.83)$ & & & $(-0.88)$ & & & $(-1.41)$ & & & $(-0.13)$ & \\
\hline Difference of Buy $B / A$ from (3) & & & & & & & & & & & -0.00153 & & & -0.00039 & & & -0.00003 & \\
\hline (t-stat: $\left.\mathrm{H}_{0}=0\right)$ & & & & & & & & & & & $(-1.56)$ & & & $(-0.98)$ & & & $(-0.05)$ & \\
\hline Difference of Buy $B / A$ from (4) & & & & & & & & & & & & & & 0.00000 & & & -0.00079 & \\
\hline$\left(\mathrm{t}\right.$-stat: $\left.\mathrm{H}_{0}=0\right)$ & & & & & & & & & & & & & & $(0.01)$ & & & $(-0.73)$ & \\
\hline By daily trade-value group & 1 & 2 & 3 & 1 & 2 & 3 & 1 & 2 & 3 & 1 & 2 & 3 & 1 & 2 & 3 & 1 & $\frac{(1.2)}{2}$ & 3 \\
\hline Avg. of median trade val (000) & 37,372 & 200,1011 & $1,185,503$ & 27,133 & 172,992 & 834,685 & 33,217 & 162,028 & 814,379 & 14,162 & 148,856 & 758,083 & 27,909 & 163,586 & 948,800 & 29,318 & 175,1871 & $\overline{1,104,860}$ \\
\hline Avg. of $A$ (in won) & 46,654 & 38,851 & 26,283 & 19,509 & 24,976 & 34,959 & 22,420 & 28,503 & 38,360 & 25,527 & 26,366 & 54,906 & 21,233 & 26,652 & 34,601 & 27,287 & 33,073 & 46,541 \\
\hline Average of Buy $B / A$ & 0.99408 & 0.99757 & 0.99933 & 0.99875 & 0.99902 & 0.99916 & 0.99782 & 0.99917 & 0.99969 & 0.99989 & 1.00168 & 0.99894 & 0.99763 & 0.99897 & $\begin{array}{r}1.00016 \\
(091)\end{array}$ & 0.99796 & 0.99939 & 1.00003 \\
\hline & $(-17.34)$ & $(-11.24)$ & $(-3.77)$ & $(-3.73)$ & $(-4.79)$ & $(-4.76)$ & $(-5.90)$ & $(-2.41)$ & $(-0.96)$ & $(-0.20)$ & $(1.69)$ & $(-0.59)$ & $(-6.62)$ & $(-3.24)$ & $(0.91)$ & $(-3.38)$ & $(-1.51)$ & $(0.10)$ \\
\hline Avg. of Median & 0.99905 & 0.99990 & 0.99999 & 1.00035 & 1.00018 & 0.99997 & 0.99858 & 1.00026 & 1.00021 & 1.00048 & 1.00193 & 1.00019 & 0.99947 & $7 \quad 1.00026$ & 1.00025 & 0.99823 & 1.00012 & 1.00018 \\
\hline Avg. of Std dev & 5.73772 & 5.22461 & 7.87589 & 16.41073 & 16.138861 & 19.22510 & 20.22828 & 22.71745 & 24.69944 & 23.85545 & 30.054173 & 36.75207 & 15.65680 & 14.79198 & 16.26386 & 20.05277 & 16.72205 & 18.83680 \\
\hline Avg \# of stocks per day & 19.7 & 45.1 & 76.2 & 32.7 & 29.1 & 19.7 & 15.8 & 13.7 & 5.4 & 6.5 & 1.7 & 1.3 & 35.4 & $4 \quad 26.3$ & 15.9 & 5.8 & 4.0 & 2.6 \\
\hline $\begin{array}{l}\text { Avg. of Sell } B / A-\text { Buy } B / A \\
\text { (t-stat: } \mathrm{H}_{0}=0 \text { ) }\end{array}$ & $\begin{array}{r}0.00717 \\
(20.39)\end{array}$ & $\begin{array}{c}0.00371 \\
(19.05)\end{array}$ & $\begin{array}{c}0.00160 \\
(12.45)\end{array}$ & $\begin{array}{r}-0.00027 \\
(-0.63)\end{array}$ & $\begin{array}{r}0.00045 \\
(1.53)\end{array}$ & $\begin{array}{r}0.00052 \\
(1.88)\end{array}$ & $\begin{array}{r}0.00349 \\
(4.80)\end{array}$ & $\begin{array}{r}0.00261 \\
(4.02)\end{array}$ & $\begin{array}{r}0.00225 \\
(4.20)\end{array}$ & $\begin{array}{c}0.00760 \\
(3.81)\end{array}$ & $\begin{array}{r}0.00674 \\
(2.16)\end{array}$ & $\begin{array}{r}0.00390 \\
(0.61)\end{array}$ & $\begin{array}{r}0.00254 \\
(5.05)\end{array}$ & $\begin{array}{rr}4 & -0.00001 \\
) & (-0.02)\end{array}$ & $\begin{array}{r}-0.00138 \\
(-5.58)\end{array}$ & $\begin{array}{r}-0.00133 \\
(-0.96)\end{array}$ & $\begin{array}{r}0.00063 \\
(0.67)\end{array}$ & $\begin{array}{r}-0.00180 \\
(-2.38)\end{array}$ \\
\hline $\begin{array}{l}\text { Difference of Buy } B / A \text { from (1) } \\
\left.\text { (t-stat: } \mathrm{H}_{0}=0\right)\end{array}$ & & & & $\begin{array}{r}0.00045 \\
(1.40)\end{array}$ & $\begin{array}{r}0.00025 \\
(1.21)\end{array}$ & $\begin{array}{r}-0.00015 \\
(-0.57)\end{array}$ & $\begin{array}{r}0.00160 \\
(4.31)\end{array}$ & $\begin{array}{r}0.00037 \\
(1.07)\end{array}$ & $\begin{array}{r}-0.00066 \\
(-1.49)\end{array}$ & $\begin{array}{r}-0.00045 \\
(-0.78)\end{array}$ & $\begin{array}{r}-0.00301 \\
(-2.52)\end{array}$ & $\begin{array}{r}-0.00064 \\
(-0.28)\end{array}$ & $\begin{array}{r}0.00184 \\
(5.52)\end{array}$ & $\begin{array}{r}0.00028 \\
(1.14)\end{array}$ & $\begin{array}{r}-0.00148 \\
(-6.29)\end{array}$ & $\begin{array}{r}0.00110 \\
(1.90)\end{array}$ & $\begin{array}{r}-0.00025 \\
(-0.56)\end{array}$ & $\begin{array}{r}-0.00180 \\
(-3.42)\end{array}$ \\
\hline Difference of Buy $B / A$ from (2) & & & & & & & 0.00212 & 0.00003 & -0.00075 & -0.00016 & -0.00093 & -0.00041 & 0.00254 & 0.00028 & -0.00167 & 0.00061 & -0.00016 & -0.00123 \\
\hline (t-stat: $\left.\mathrm{H}_{0}=0\right)$ & & & & & & & $(4.47)$ & $(0.07)$ & $(-1.68)$ & $(-0.23)$ & $(-0.56)$ & $(-0.18)$ & (5.94) & $\quad(0.74)$ & $(-5.82)$ & $(0.76)$ & $(-0.31)$ & $(-1.87)$ \\
\hline $\begin{array}{l}\text { Difference of Buy } B / A \text { from (3) } \\
\text { (t-stat: } \mathrm{H}_{0}=0 \text { ) }\end{array}$ & & & & & & & & & & -0.00100 & -0.00382 & 0.00580 & 0.00266 & $6-0.00047$ & -0.00154 & 0.00283 & -0.00133 & -0.00101 \\
\hline $\begin{array}{l}\left(\mathrm{t} \text {-stat: } \mathrm{H}_{0}=0\right) \\
\text { Difference of Buy } B / A \text { from (4) }\end{array}$ & & & & & & & & & & & & & $\begin{array}{r}(4.13) \\
0.00308\end{array}$ & $\begin{aligned} &(-0.81) \\
& 8-0.00061\end{aligned}$ & $\begin{array}{r}(-3.19) \\
-0.00061\end{array}$ & $\begin{array}{r}(2.71) \\
-0.00131\end{array}$ & $\begin{array}{c}(-1.75) \\
0.00026\end{array}$ & $\begin{array}{r}(-1.00) \\
-0.00301\end{array}$ \\
\hline (t-stat: $\left.\mathrm{H}_{0}=0\right)$ & & & & & & & & & & & & & $(2.00)$ & $\quad(-0.60)$ & $(-0.70)$ & $(-0.51)$ & $(0.17)$ & $(-1.85)$ \\
\hline Difference of Buy $B / A$ from (5) & & & & & & & & & & & & & & & & 0.00159 & 0.00050 & -0.00045 \\
\hline (t-stat: $\left.\mathrm{H}_{0}=0\right)$ & & & & & & & & & & & & & & & & (2.32) & $(1.12)$ & $(-1.06)$ \\
\hline
\end{tabular}


Table 1. (Continued)

Panel C. Sell prices, equally weighted across stocks and then across days

\begin{tabular}{|c|c|c|c|c|c|c|c|c|c|c|c|c|c|c|c|c|c|c|}
\hline \multirow[b]{2}{*}{$\begin{array}{l}\text { All groups of daily trade- } \\
\text { value }\end{array}$} & \multicolumn{9}{|c|}{ Domestic investors } & \multicolumn{9}{|c|}{ Non-resident foreign investors } \\
\hline & \multicolumn{3}{|c|}{ (1) Individual } & \multicolumn{3}{|c|}{$\begin{array}{l}\text { (2) Securities, Mutual, } \\
\text { Pension funds }\end{array}$} & \multicolumn{3}{|c|}{$\begin{array}{l}\text { (3) Banks, Insurance, } \\
\text { Merchant banks }\end{array}$} & \multicolumn{3}{|c|}{ (4) Individual } & \multicolumn{3}{|c|}{$\begin{array}{l}\text { (5) Securities, Mutual, } \\
\text { Pension funds }\end{array}$} & \multicolumn{3}{|c|}{$\begin{array}{l}\text { (6) Banks, Insurance, } \\
\text { Merchant banks }\end{array}$} \\
\hline$\overline{\text { Avg. of median trade val }(000)}$ & & 465,193 & & & 96,365 & & & 107,552 & & & 18,138 & & & 104,273 & & & 132,583 & \\
\hline Avg. of $A$ (in won) & & 23,953 & & & 25,040 & & & 24,816 & & & 23,662 & & & 25,275 & & & 26,734 & \\
\hline Average of Sell $B / A$ & & 1.00106 & & & 0.99838 & & & 1.00030 & & & 1.00043 & & & 0.99968 & & & 0.99947 & \\
\hline$\left(\mathrm{t}\right.$-stat: $\left.\mathrm{H}_{0}=1\right)$ & & $(30.93)$ & & & $(-14.40)$ & & & $(1.90)$ & & & $(1.12)$ & & & $(-3.53)$ & & & $(-2.19)$ & \\
\hline Avg. of Median & & 1.00009 & & & 0.99918 & & & 1.00016 & & & 1.00019 & & & 0.99957 & & & 0.99934 & \\
\hline Avg. of Std dev & & 0.00576 & & & 0.01388 & & & 0.01388 & & & 0.01569 & & & 0.01274 & & & 0.01023 & \\
\hline Avg \# of stocks per day & & 141.4 & & & 103.7 & & & 40.2 & & & 6.7 & & & 79.5 & & & 10.1 & \\
\hline Avg. of Sell $B / A-$ Buy $B / A$ & & 0.00225 & & & -0.00098 & & & 0.00228 & & & 0.00691 & & & -0.00041 & & & -0.00043 & \\
\hline$\left(\mathrm{t}\right.$-stat: $\left.\mathrm{H}_{0}=0\right)$ & & $(36.68)$ & & & $(-5.82)$ & & & $(6.20)$ & & & $(4.21)$ & & & $(-2.22)$ & & & $(-0.70)$ & \\
\hline Difference of Sell $B / A$ from (1) & & & & & 0.00281 & & & 0.00092 & & & 0.00013 & & & 0.00162 & & & 0.00166 & \\
\hline (t-stat: $\left.\mathrm{H}_{0}=0\right)$ & & & & & $(21.87)$ & & & $(5.18)$ & & & $(0.32)$ & & & $(14.03)$ & & & $(6.02)$ & \\
\hline Difference of Sell $B / A$ from (2) & & & & & & & & -0.00157 & & & -0.00094 & & & -0.00067 & & & -0.00064 & \\
\hline (t-stat: $\left.\mathrm{H}_{0}=0\right)$ & & & & & & & & $(-7.37)$ & & & $(-1.66)$ & & & $(-4.12)$ & & & $(-1.82)$ & \\
\hline Difference of Sell $B / A$ from (3) & & & & & & & & & & & -0.00061 & & & 0.00133 & & & 0.00136 & \\
\hline (t-stat: $\left.\mathrm{H}_{0}=0\right)$ & & & & & & & & & & & $(-0.71)$ & & & $(5.32)$ & & & $(2.47)$ & \\
\hline Difference of Sell $B / A$ from (4) & & & & & & & & & & & & & & 0.00186 & & & 0.00162 & \\
\hline$\left(\mathrm{t}\right.$-stat: $\left.\mathrm{H}_{0}=0\right)$ & & & & & & & & & & & & & & (2.94) & & & $(1.35)$ & \\
\hline Difference of Sell $B / A$ from (5) & & & & & & & & & & & & & & & & & 0.00017 & \\
\hline$\left(\mathrm{t}\right.$-stat: $\left.\mathrm{H}_{0}=0\right)$ & & & & & & & & & & & & & & & & & $(0.55)$ & \\
\hline By daily trade-value group & 1 & 2 & 3 & 1 & 2 & 3 & 1 & 2 & 3 & 1 & 2 & 3 & 1 & 2 & 3 & 1 & 2 & 3 \\
\hline Avg. of median trade val (000) & 38,342 & 185,4801 & $1,096,938$ & 11,551 & 160,739 & 788,232 & 29,296 & 151,076 & 767,773 & 12,473 & 131,010 & 787,116 & 26,004 & 153,118 & 865,500 & 26,587 & 164,925 & 919,642 \\
\hline Avg. of $A$ (in won) & 29,598 & 24,124 & 22,866 & 20,585 & 25,630 & 33,921 & 20,688 & 25,389 & 34,263 & 22,552 & 23,263 & 69,398 & 21,579 & 26,419 & 30,210 & 23,287 & 28,673 & 31,930 \\
\hline Average of Sell $B / A$ & 1.00215 & 1.00126 & 1.00077 & 0.99784 & 0.99913 & 0.99886 & 1.00148 & 0.99986 & 0.99946 & 1.00057 & 1.00116 & 1.00259 & 1.00126 & 0.99859 & 0.99841 & 1.00054 & 0.99893 & 0.99863 \\
\hline$\left(\mathrm{t}-\mathrm{stat}: \mathrm{H}_{0}=1\right)$ & $(15.12)$ & (23.95) & $(25.52)$ & $(-11.38)$ & $(-8.09)$ & $(-9.84)$ & $(5.56)$ & $(-0.75)$ & $(-2.22)$ & $(1.38)$ & $(1.01)$ & $(1.24)$ & $(7.41)$ & $(-11.85)$ & $(-15.45)$ & $(1.25)$ & $(-3.01)$ & $(-4.60)$ \\
\hline Avg. of Median & 1.00040 & 1.00011 & 1.00012 & 0.99878 & 0.99938 & 0.99922 & 1.00135 & 1.00007 & 0.99960 & 1.00049 & 1.00115 & 1.00255 & 1.00076 & 0.99903 & 0.99900 & 1.00031 & 0.99908 & 0.99881 \\
\hline Avg. of Std dev & 0.00964 & 0.00558 & 0.00375 & 0.01720 & 0.01051 & 0.00737 & 0.01594 & 0.01199 & 0.00896 & 0.01586 & 0.01448 & 0.00904 & 0.01553 & 30.01029 & 0.00692 & 0.01198 & 0.00764 & 0.00576 \\
\hline Avg \# of stocks per day & 16.0 & 47.2 & 78.3 & 46.6 & 32.7 & 24.4 & 16.5 & 15.9 & 8.1 & 6.1 & 1.7 & 1.3 & 34.5 & $\quad 28.7$ & 16.3 & 5.7 & 3.7 & 2.3 \\
\hline $\begin{array}{l}\text { Avg. of Sell } B / A-\text { Buy } B / A \\
\left.\text { (t-stat: } \mathrm{H}_{0}=0\right)\end{array}$ & $\begin{array}{c}0.00442 \\
(22.81)\end{array}$ & $\begin{array}{c}0.00281 \\
(31.00)\end{array}$ & $\begin{array}{c}0.00143 \\
(28.64)\end{array}$ & $\begin{array}{r}-0.00188 \\
(-6.72)\end{array}$ & $\begin{array}{r}-0.00062 \\
(-3.07)\end{array}$ & $\begin{array}{r}-0.00005 \\
(-0.29)\end{array}$ & $\begin{array}{r}0.00267 \\
(4.15)\end{array}$ & $\begin{array}{r}0.00295 \\
(5.66)\end{array}$ & $\begin{array}{r}0.00107 \\
(1.94)\end{array}$ & $\begin{array}{r}0.00673 \\
(3.78)\end{array}$ & $\begin{array}{r}0.00721 \\
(2.13)\end{array}$ & $\begin{array}{r}0.00948 \\
(0.81)\end{array}$ & $\begin{array}{r}0.00139 \\
(3.24)\end{array}$ & $\begin{array}{r}-0.00105 \\
(-3.59)\end{array}$ & $\begin{array}{r}-0.00117 \\
(-5.90)\end{array}$ & $\begin{array}{r}0.00112 \\
(0.95)\end{array}$ & $\begin{array}{r}-0.00166 \\
(-1.66)\end{array}$ & $\begin{array}{r}-0.00144 \\
(-1.84)\end{array}$ \\
\hline $\begin{array}{l}\text { Difference of Sell } B / A \text { from (1) } \\
\left(\mathrm{t} \text {-stat: } \mathrm{H}_{0}=0\right)\end{array}$ & & & & $\begin{array}{r}0.00291 \\
(14.37)\end{array}$ & $\begin{array}{c}0.00230 \\
(16.30)\end{array}$ & $\begin{array}{r}0.00293 \\
(16.65)\end{array}$ & $\begin{array}{r}-0.00038 \\
(-1.33)\end{array}$ & $\begin{array}{r}0.00139 \\
(6.17)\end{array}$ & $\begin{array}{r}0.00206 \\
(6.24)\end{array}$ & $\begin{array}{r}-0.00007 \\
(-0.16)\end{array}$ & $\begin{array}{r}-0.00046 \\
(-0.38)\end{array}$ & $\begin{array}{r}-0.00143 \\
(-0.52)\end{array}$ & $\begin{array}{r}-0.00050 \\
(-2.61)\end{array}$ & $\begin{array}{r}0.00294 \\
(18.59)\end{array}$ & $\begin{array}{r}0.00353 \\
(20.83)\end{array}$ & $\begin{array}{r}0.00049 \\
(1.00)\end{array}$ & $\begin{array}{r}0.00207 \\
(5.07)\end{array}$ & $\begin{array}{r}0.00345 \\
(8.56)\end{array}$ \\
\hline Difference of Sell $B / A$ from (2) & & & & & & & -0.00322 & -0.00125 & 0.00002 & -0.00131 & -0.00091 & -0.00277 & -0.00325 & 0.00017 & 0.00170 & -0.00203 & 0.00016 & 0.00124 \\
\hline (t-stat: $\mathrm{H}_{0}=0$ ) & & & & & & & $(-8.28)$ & $(-4.03)$ & $(0.06)$ & $(-2.15)$ & $(-0.59)$ & $(-1.09)$ & $(-11.29)$ & $(0.73)$ & (7.90) & $(-3.43)$ & $(0.29)$ & (2.34) \\
\hline Difference of Sell $B / A$ from (3) & & & & & & & & & & -0.00083 & 0.00311 & -0.01178 & -0.00073 & 0.00170 & 0.00299 & 0.00060 & 0.00209 & 0.00221 \\
\hline$\left(\mathrm{t}\right.$-stat: $\left.\mathrm{H}_{0}=0\right)$ & & & & & & & & & & $(-0.86)$ & $(1.56)$ & $(-1.45)$ & $(-1.38)$ & (4.55) & (6.94) & $(0.64)$ & $(2.78)$ & (3.02) \\
\hline Difference of Sell $B / A$ from (4) & & & & & & & & & & & & & -0.00053 & 0.00101 & 0.00351 & -0.00016 & 0.00414 & 0.00308 \\
\hline (t-stat: $\mathrm{H}_{0}=0$ ) & & & & & & & & & & & & & $(-0.44)$ & $(0.94)$ & (3.95) & $(-0.09)$ & $(2.20)$ & $(1.52)$ \\
\hline Difference of Sell $B / A$ from (5) & & & & & & & & & & & & & & & & -0.00068 & 0.00032 & 0.00073 \\
\hline (t-stat: $\left.\mathrm{H}_{0}=0\right)$ & & & & & & & & & & & & & & & & $(-1.15)$ & $(0.67)$ & $(1.57)$ \\
\hline
\end{tabular}


Table 1. (Continued)

Panel D. Sell prices, weighted by trade value across stocks and then across days

\begin{tabular}{|c|c|c|c|c|c|c|c|c|c|c|c|c|c|c|c|c|c|c|}
\hline \multirow[b]{2}{*}{$\begin{array}{l}\text { All groups of daily trade- } \\
\text { value }\end{array}$} & \multicolumn{9}{|c|}{ Domestic investors } & \multicolumn{9}{|c|}{ Non-resident foreign investors } \\
\hline & \multicolumn{3}{|c|}{ (1) Individual } & \multicolumn{3}{|c|}{$\begin{array}{l}\text { (2) Securities, Mutual, } \\
\text { Pension funds }\end{array}$} & \multicolumn{3}{|c|}{$\begin{array}{l}\text { (3) Banks, Insurance, } \\
\text { Merchant banks }\end{array}$} & \multicolumn{3}{|c|}{ (4) Individual } & \multicolumn{3}{|c|}{$\begin{array}{l}\text { (5) Securities, Mutual, } \\
\text { Pension funds }\end{array}$} & \multicolumn{3}{|c|}{$\begin{array}{l}\text { (6) Banks, Insurance, } \\
\text { Merchant banks }\end{array}$} \\
\hline$\overline{\text { Avg. of median trade val }(000)}$ & & 465,193 & & & 96,365 & & & 107,552 & & & 18,138 & & & 104,273 & & & 132,583 & \\
\hline Avg. of $A$ (in won) & & 27,646 & & & 28,143 & & & 29,634 & & & 28,028 & & & 28,045 & & & 28,723 & \\
\hline Average of Sell $B / A$ & & 1.00091 & & & 0.99905 & & & 1.00068 & & & 1.00109 & & & 0.99894 & & & 0.99955 & \\
\hline$\left(\mathrm{t}\right.$-stat: $\left.\mathrm{H}_{0}=1\right)$ & & $(10.31)$ & & & $(-5.27)$ & & & $(3.23)$ & & & $(2.10)$ & & & $(-6.31)$ & & & $(-1.44)$ & \\
\hline Avg. of Median & & 1.00009 & & & 0.99918 & & & 1.00016 & & & 1.00019 & & & 0.99957 & & & 0.99934 & \\
\hline Avg. of Std dev & & 6.77916 & & & 18.30158 & & & 24.69968 & & & 24.76235 & & & 18.63948 & & & 20.22209 & \\
\hline Avg \# of stocks per day & & 141.4 & & & 103.7 & & & 40.2 & & & 6.7 & & & 79.5 & & & 10.1 & \\
\hline Avg. of Sell $B / A-$ Buy $B / A$ & & 0.00189 & & & 0.00041 & & & 0.00273 & & & 0.00740 & & & -0.00035 & & & -0.00019 & \\
\hline$\left(\mathrm{t}\right.$-stat: $\left.\mathrm{H}_{0}=0\right)$ & & $(15.03)$ & & & $(1.66)$ & & & $(6.00)$ & & & (4.17) & & & $(-1.46)$ & & & $(-0.30)$ & \\
\hline Difference of Sell $B / A$ from (1) & & & & & 0.00190 & & & 0.00024 & & & -0.00040 & & & 0.00211 & & & 0.00139 & \\
\hline (t-stat: $\left.\mathrm{H}_{0}=0\right)$ & & & & & (11.46) & & & $(1.00)$ & & & $(-0.77)$ & & & $(12.92)$ & & & $(4.08)$ & \\
\hline Difference of Sell $B / A$ from (2) & & & & & & & & -0.00170 & & & -0.00161 & & & 0.00037 & & & -0.00028 & \\
\hline (t-stat: $\left.\mathrm{H}_{0}=0\right)$ & & & & & & & & $(-6.05)$ & & & $(-2.48)$ & & & $(1.89)$ & & & $(-0.63)$ & \\
\hline Difference of Sell $B / A$ from (3) & & & & & & & & & & & -0.00102 & & & 0.00211 & & & 0.00134 & \\
\hline (t-stat: $\left.\mathrm{H}_{0}=0\right)$ & & & & & & & & & & & $(-1.19)$ & & & $(6.69)$ & & & $(2.32)$ & \\
\hline Difference of Sell $B / A$ from (4) & & & & & & & & & & & & & & 0.00230 & & & 0.00175 & \\
\hline$\left(\mathrm{t}\right.$-stat: $\left.\mathrm{H}_{0}=0\right)$ & & & & & & & & & & & & & & $(3.23)$ & & & (1.41) & \\
\hline Difference of Sell $B / A$ from (5) & & & & & & & & & & & & & & & & & -0.00004 & \\
\hline$\left(\mathrm{t}\right.$-stat: $\left.\mathrm{H}_{0}=0\right)$ & & & & & & & & & & & & & & & & & $(-0.10)$ & \\
\hline By daily trade-value group & 1 & 2 & 3 & 1 & 2 & 3 & 1 & 2 & 3 & 1 & 2 & 3 & 1 & 2 & 3 & 1 & 2 & 3 \\
\hline Avg. of median trade val (000) & 38,342 & 185,4801 & $1,096,938$ & 11,551 & 160,739 & 788,232 & 29,296 & 151,076 & 767,773 & 12,473 & 131,010 & 787,116 & 26,004 & 153,118 & 865,500 & 26,587 & 164,925 & 919,642 \\
\hline Avg. of $A$ (in won) & 39,489 & 32,849 & 27,137 & 20,003 & 22,725 & 33,198 & 21,586 & 26,433 & 35,782 & 26,730 & 23,626 & 70,127 & 23,170 & 26,365 & 29,840 & 24,663 & 28,085 & 31,186 \\
\hline Average of Sell $B / A$ & 1.00345 & 1.00211 & 1.00079 & 0.99829 & 0.99976 & 0.99906 & 1.00175 & 1.00075 & 1.00004 & 1.00127 & 1.00105 & 1.00272 & 1.00053 & 0.99907 & 0.99828 & 1.00082 & 0.99905 & 0.99859 \\
\hline$\left(\mathrm{t}-\mathrm{stat}: \mathrm{H}_{0}=1\right)$ & $(10.68)$ & $(17.85)$ & $(8.57)$ & $(-6.37)$ & $(-1.13)$ & $(-4.63)$ & $(4.49)$ & (2.62) & $(0.15)$ & $(2.29)$ & $(0.88)$ & $(1.26)$ & $(1.53)$ & $(-3.72)$ & $(-9.13)$ & $(1.57)$ & $(-2.30)$ & $(-3.91)$ \\
\hline Avg. of Median & 1.00040 & 1.00011 & 1.00012 & 0.99878 & 0.99938 & 0.99922 & 1.00135 & 1.00007 & 0.99960 & 1.00049 & 1.00115 & 1.00255 & 1.00076 & $6 \quad 0.99903$ & 0.99900 & 1.00031 & 0.99908 & 0.99881 \\
\hline Avg. of Std dev & 4.15096 & 4.51144 & 7.40974 & 16.75079 & 15.40833 & 18.51768 & 20.59977 & 21.80155 & 25.18769 & 23.13295 & 39.987852 & 25.02975 & 16.27055 & 16.09845 & 17.57417 & 17.03731 & 15.40508 & 19.54788 \\
\hline Avg \# of stocks per day & 16.0 & 47.2 & 78.3 & 46.6 & $5 \quad 32.7$ & 24.4 & $\quad 16.5$ & 15.9 & 8.1 & 6.1 & 1.7 & 1.3 & 34.5 & $5 \quad 28.7$ & 16.3 & 5.7 & 3.7 & 2.3 \\
\hline $\begin{array}{l}\text { Avg. of Sell } B / A-\text { Buy } B / A \\
\left.\text { (t-stat: } \mathrm{H}_{0}=0\right)\end{array}$ & $\begin{array}{r}0.00565 \\
(17.29)\end{array}$ & $\begin{array}{c}0.00366 \\
(19.09)\end{array}$ & $\begin{array}{c}0.00168 \\
(13.07)\end{array}$ & $\begin{array}{r}-0.00092 \\
(-2.27)\end{array}$ & $\begin{array}{r}0.00060 \\
(2.02)\end{array}$ & $\begin{array}{r}0.00049 \\
(1.73)\end{array}$ & $\begin{array}{r}0.00343 \\
(5.03)\end{array}$ & $\begin{array}{r}0.00360 \\
(6.07)\end{array}$ & $\begin{array}{r}0.00155 \\
(2.48)\end{array}$ & $\begin{array}{c}0.00686 \\
(3.58)\end{array}$ & $\begin{array}{r}0.00694 \\
(2.05)\end{array}$ & $\begin{array}{r}0.00898 \\
(0.77)\end{array}$ & $\begin{array}{r}0.00152 \\
(2.84)\end{array}$ & $\begin{array}{r}-0.00014 \\
(-0.35)\end{array}$ & $\begin{array}{r}-0.00083 \\
(-3.39)\end{array}$ & $\begin{array}{r}0.00109 \\
(0.88)\end{array}$ & $\begin{array}{r}-0.00095 \\
(-0.93)\end{array}$ & $\begin{array}{r}-0.00179 \\
(-2.07)\end{array}$ \\
\hline $\begin{array}{l}\text { Difference of Sell } B / A \text { from (1) } \\
\text { (t-stat: } \mathrm{H}_{0}=0 \text { ) }\end{array}$ & & & & $\begin{array}{r}0.00223 \\
(8.23)\end{array}$ & $\begin{array}{r}0.00122 \\
(6.20)\end{array}$ & $\begin{array}{r}0.00215 \\
(9.46)\end{array}$ & $\begin{array}{r}-0.00078 \\
(-2.00)\end{array}$ & $\begin{array}{r}0.00021 \\
(0.71)\end{array}$ & $\begin{array}{r}0.00113 \\
(3.00)\end{array}$ & $\begin{array}{r}-0.00066 \\
(-1.16)\end{array}$ & $\begin{array}{r}-0.00049 \\
(-0.40)\end{array}$ & $\begin{array}{r}-0.00149 \\
(-0.54)\end{array}$ & $\begin{array}{r}-0.00004 \\
(-0.11)\end{array}$ & $\begin{array}{r}0.00200 \\
(8.89)\end{array}$ & $\begin{array}{r}0.00312 \\
(14.07)\end{array}$ & $\begin{array}{r}0.00018 \\
(0.32)\end{array}$ & $\begin{array}{r}0.00179 \\
(3.82)\end{array}$ & $\begin{array}{r}0.00331 \\
(7.42)\end{array}$ \\
\hline Difference of Sell $B / A$ from (2) & & & & & & & -0.00296 & -0.00184 & -0.00081 & -0.00199 & -0.00043 & -0.00322 & -0.00213 & -0.00005 & 0.00149 & -0.00176 & -0.00016 & 0.00131 \\
\hline (t-stat: $\mathrm{H}_{0}=0$ ) & & & & & & & $(-6.41)$ & $(-5.35)$ & $(-1.95)$ & $(-2.85)$ & $(-0.28)$ & $(-1.27)$ & $(-5.09)$ & $(-0.14)$ & $(5.82)$ & $(-2.74)$ & $(-0.25)$ & (2.40) \\
\hline Difference of Sell $B / A$ from (3) & & & & & & & & & & -0.00116 & 0.00252 & -0.01127 & 0.00023 & $3 \quad 0.00099$ & 0.00323 & 0.00090 & 0.00203 & 0.00226 \\
\hline$\left(\mathrm{t}\right.$-stat: $\left.\mathrm{H}_{0}=0\right)$ & & & & & & & & & & $(-1.19)$ & $(1.26)$ & $(-1.39)$ & $(0.35)$ & (2.11) & (6.73) & $(0.92)$ & (2.58) & (3.01) \\
\hline Difference of Sell $B / A$ from (4) & & & & & & & & & & & & & -0.00049 & 0.00050 & 0.00337 & 0.00027 & 0.00378 & 0.00314 \\
\hline (t-stat: $\mathrm{H}_{0}=0$ ) & & & & & & & & & & & & & $(-0.37)$ & $(0.45)$ & (3.61) & $(0.14)$ & $(2.01)$ & (1.54) \\
\hline Difference of Sell $B / A$ from (5) & & & & & & & & & & & & & & & & -0.00075 & 0.00006 & 0.00047 \\
\hline$\left(\mathrm{t}\right.$-stat: $\left.\mathrm{H}_{0}=0\right)$ & & & & & & & & & & & & & & & & $(-1.17)$ & $(0.12)$ & $(0.96)$ \\
\hline
\end{tabular}


Table 2. Average proportion (\%) of intraday trading volume for each type of investor

This table reports the average proportions (\%) of intraday trading volume for each of three classes of investors relative to the total trading volume for the interval and for the day (both in shares and values, respectively). The three classes of investors include (1) Korean individuals (2) Korean money managers (securities, mutual, pension funds) and banks (banks, insurance, merchant banks), and (3) Foreign money managers and banks (including resident foreigners).

\begin{tabular}{|c|c|c|c|c|c|c|c|c|c|c|c|c|}
\hline \multirow{3}{*}{ Trading intervals } & \multicolumn{6}{|c|}{ Relative to the trading volume for the interval } & \multicolumn{6}{|c|}{ Relative to the trading volume for the day } \\
\hline & \multicolumn{3}{|c|}{ (in values) } & \multicolumn{3}{|c|}{ (in shares) } & \multicolumn{3}{|c|}{ (in values) } & \multicolumn{3}{|c|}{ (in shares) } \\
\hline & (1) & (2) & (3) & (1) & $(2)$ & (3) & (1) & $(2)$ & (3) & (1) & $(2)$ & (3) \\
\hline Morning opening batch & 75.0 & 12.4 & 12.7 & 81.8 & 8.8 & 9.4 & 2.9 & 0.7 & 0.7 & 3.9 & 0.5 & 0.5 \\
\hline $9: 30-10: 30$ & 71.4 & 17.0 & 11.6 & 76.9 & 13.7 & 9.5 & 18.8 & 4.5 & 3.0 & 20.6 & 3.6 & 2.4 \\
\hline $10: 30-11: 30$ & 68.8 & 17.2 & 14.0 & 74.3 & 14.2 & 11.5 & 15.8 & 3.9 & 3.1 & 17.0 & 3.2 & 2.6 \\
\hline Afternoon opening batch & 70.1 & 12.8 & 17.1 & 77.8 & 9.2 & 13.0 & 1.4 & 0.3 & 0.4 & 1.9 & 0.2 & 0.3 \\
\hline $13: 00-14: 00$ & 65.2 & 17.9 & 16.9 & 71.6 & 14.6 & 13.8 & 10.5 & 3.0 & 2.8 & 11.6 & 2.4 & 2.2 \\
\hline $14: 00-14: 50$ & 65.6 & 18.0 & 16.5 & 71.5 & 14.8 & 13.7 & 11.6 & 3.2 & 3.0 & 12.4 & 2.6 & 2.4 \\
\hline Closing batch & 62.2 & 18.7 & 19.1 & 67.8 & 15.9 & 16.3 & 4.4 & 1.4 & 1.4 & 4.5 & 1.1 & 1.1 \\
\hline Extended trading hours & 60.4 & 20.5 & 19.1 & 65.4 & 17.3 & 17.3 & 0.2 & 0.4 & 0.2 & 0.2 & 0.2 & 0.3 \\
\hline
\end{tabular}




\section{Table 3. Daily trade proportions of various investor classes around firm-specific information days (12/2/96 11/30/98: 586 days)}

For each type of investor, the proportion of daily buy and sell trade values is calculated as relative to the total trade value for the stock-days with at least one foreign trade and with a market model residual over 5\% in absolute values (excluding events with overlapping windows for a stock). The market model is estimated from Oct. 2, 1996 to Nov. 30, 1998, and daily closing prices falling below 1,000 won are treated as missing in calculating daily returns to minimize low-price effects. The reported value in each cell is the average across stocks on a day and then across days. NR stands for non-resident.

Panel A. Buy proportion on Positive 5\% AR days (10.5 stocks per event of 559 days)

\begin{tabular}{|c|c|c|c|c|c|c|c|c|c|c|c|c|c|c|}
\hline Buy Proportion & D-5 & D-4 & D-3 & D-2 & D-1 & D0 & $\mathrm{D}+1$ & $\mathbf{D}+2$ & $\mathbf{D}+\mathbf{3}$ & $\mathrm{D}+4$ & $\mathrm{D}+5$ & $\operatorname{Avg}(-5,-1)$ & $\operatorname{Avg}(+1,+5$ & Avg Diff \\
\hline Korean Individuals & 82.48 & 82.88 & 82.99 & 83.18 & 83.26 & 76.04 & 81.11 & 81.23 & 81.70 & 82.04 & 82.11 & 82.93 & 81.54 & 1.39 \\
\hline Korean Money managers & 8.18 & 8.18 & 8.03 & 8.25 & 7.87 & 8.57 & 8.08 & 8.36 & 7.86 & 8.48 & 7.76 & 8.10 & 8.15 & -0.05 \\
\hline Korean Banks & 2.22 & 2.15 & 2.05 & 1.74 & 1.85 & 2.04 & 2.05 & 2.21 & 2.10 & 2.13 & 2.24 & 2.00 & 2.15 & -0.15 \\
\hline NR Foreign Individuals & 0.07 & 0.07 & 0.08 & 0.08 & 0.15 & 0.33 & 0.16 & 0.14 & 0.13 & 0.08 & 0.06 & 0.09 & 0.11 & -0.03 \\
\hline NR Foreign Money managers & 5.22 & 4.88 & 4.97 & 5.05 & 5.23 & 11.01 & 7.02 & 6.31 & 6.27 & 5.35 & 5.87 & 5.10 & 6.22 & -1.12 \\
\hline NR Foreign Banks & 0.33 & 0.29 & 0.27 & 0.22 & 0.20 & 0.61 & 0.30 & 0.36 & 0.40 & 0.35 & 0.24 & 0.26 & 0.33 & -0.07 \\
\hline NR Foreigners Total & 5.61 & 5.24 & 5.32 & 5.35 & 5.58 & 11.95 & 7.47 & 6.80 & 6.80 & 5.79 & 6.17 & 5.45 & 6.66 & -1.21 \\
\hline \multicolumn{15}{|c|}{ T-value for each trade proportion } \\
\hline Korean Individuals & $(162.72)$ & $(163.51)$ & $(163.37)$ & $(165.91)$ & $(173.60)$ & $(123.91)$ & $(147.14)$ & $(156.85)$ & (161.04) & $(159.38)$ & $(155.48)$ & $(203.02)$ & $(181.17)$ & $(4.29)$ \\
\hline Korean Money managers & $(23.71)$ & $(23.25)$ & $(22.80)$ & $(22.66)$ & $(25.11)$ & $(24.32)$ & $(25.27)$ & $(24.56)$ & $(25.48)$ & $(24.16)$ & $(25.93)$ & $(30.35)$ & $(31.63)$ & $(-0.23)$ \\
\hline Korean Banks & $(14.23)$ & (13.93) & (11.93) & $(14.57)$ & $(16.41)$ & $(15.01)$ & $(15.90)$ & $(16.21)$ & $(17.34)$ & $(14.31)$ & $(13.61)$ & $(22.33)$ & $(23.14)$ & $(-1.60)$ \\
\hline NR Foreign Individuals & $(2.30)$ & $(2.45)$ & $(3.59)$ & $(3.50)$ & $(1.87)$ & $(4.14)$ & $(3.82)$ & $(3.73)$ & $(3.88)$ & $(3.83)$ & $(4.98)$ & $(3.78)$ & $(5.88)$ & $(-0.96)$ \\
\hline NR Foreign Money managers & $(18.40)$ & (18.06) & (18.06) & $(18.01)$ & $(16.86)$ & $(25.02)$ & (19.38) & $(18.87)$ & $(17.81)$ & $(18.04)$ & $(16.16)$ & (23.76) & $(22.27)$ & $(-4.80)$ \\
\hline NR Foreign Banks & $(5.48)$ & $(4.71)$ & $(5.65)$ & $(6.68)$ & $(6.18)$ & $(6.35)$ & $(7.08)$ & $(6.23)$ & $(5.88)$ & $(6.41)$ & $(6.79)$ & (10.08) & $(9.60)$ & $(-1.79)$ \\
\hline NR Foreigners Total & $(18.89)$ & $(18.84)$ & $(18.44)$ & $(18.63)$ & $(17.19)$ & $(26.27)$ & $(20.35)$ & $(19.74)$ & (18.63) & $(18.94)$ & $(16.87)$ & (24.19) & $(23.29)$ & $(-5.12)$ \\
\hline
\end{tabular}


Table 3. (Continued)

Panel B. Sell proportion on Positive 5\% AR days (10.5 stocks per event of 559 days)

\begin{tabular}{|c|c|c|c|c|c|c|c|c|c|c|c|c|c|c|}
\hline Sell Proportion & D-5 & D-4 & D-3 & D-2 & D-1 & D0 & $\mathrm{D}+1$ & $\mathrm{D}+2$ & $\mathbf{D}+3$ & $\mathrm{D}+4$ & \multicolumn{3}{|c|}{ D+5 Avg $(-5,-1) \operatorname{Avg}(+1,+5$} & Avg Diff \\
\hline Korean Individuals & 82.49 & 82.50 & 81.75 & 81.38 & 80.14 & 78.96 & 83.92 & 84.32 & 84.51 & 84.11 & 84.00 & 81.59 & 84.15 & -2.57 \\
\hline Korean Money managers & 9.00 & 9.05 & 9.24 & 8.86 & 9.39 & 9.62 & 8.23 & 7.73 & 7.74 & 7.93 & 8.10 & 9.11 & 7.94 & 1.17 \\
\hline Korean Banks & 2.33 & 2.18 & 2.32 & 2.59 & 2.62 & 3.03 & 2.35 & 2.40 & 2.33 & 2.47 & 2.36 & 2.44 & 2.37 & 0.07 \\
\hline NR Foreign Individuals & 0.10 & 0.11 & 0.04 & 0.05 & 0.09 & 0.19 & 0.05 & 0.04 & 0.04 & 0.07 & 0.06 & 0.07 & 0.05 & 0.01 \\
\hline NR Foreign Money managers & 4.50 & 4.65 & 5.03 & 5.54 & 6.08 & 6.49 & 4.17 & 4.21 & 4.02 & 4.02 & 3.97 & 5.20 & 4.11 & 1.09 \\
\hline NR Foreign Banks & 0.34 & 0.39 & 0.35 & 0.39 & 0.37 & 0.30 & 0.23 & 0.20 & 0.29 & 0.43 & 0.46 & 0.37 & 0.32 & 0.04 \\
\hline NR Foreigners Total & 4.94 & 5.15 & 5.42 & 5.99 & 6.54 & 6.98 & 4.46 & 4.45 & 4.36 & 4.52 & 4.49 & 5.64 & 4.48 & 1.15 \\
\hline \multicolumn{15}{|c|}{ T-value for each trade proportion } \\
\hline Korean Individuals & $(177.74)$ & $(171.02)$ & $(156.60)$ & $(156.52)$ & $(151.12)$ & $(169.65)$ & $(190.58)$ & $(193.53)$ & (205.74) & $(186.86)$ & $(180.57)$ & (200.92) & $(237.90)$ & $(-8.24)$ \\
\hline Korean Money managers & $(26.07)$ & $(26.16)$ & $(25.29)$ & $(26.21)$ & $(27.00)$ & $(31.64)$ & $(26.05)$ & $(24.86)$ & $(28.55)$ & $(24.48)$ & $(25.38)$ & $(35.62)$ & $(35.12)$ & $(5.63)$ \\
\hline Korean Banks & (17.94) & (15.98) & $(16.28)$ & $(15.87)$ & (16.78) & $(19.46)$ & (19.96) & $(20.27)$ & (19.03) & (20.34) & $(18.27)$ & $(23.43)$ & $(29.52)$ & $(0.60)$ \\
\hline NR Foreign Individuals & $(2.07)$ & $(1.91)$ & $(3.50)$ & $(2.19)$ & $(2.52)$ & $(4.47)$ & $(3.85)$ & $(4.52)$ & $(3.75)$ & $(3.17)$ & $(2.87)$ & $(4.46)$ & $(5.79)$ & $(0.95)$ \\
\hline NR Foreign Money managers & (16.68) & (17.34) & $(17.46)$ & (17.08) & $(16.05)$ & $(23.86)$ & (16.19) & $(17.92)$ & (18.24) & $(18.70)$ & $(17.32)$ & (21.69) & $(24.32)$ & $(4.76)$ \\
\hline NR Foreign Banks & $(5.09)$ & $(4.70)$ & $(4.66)$ & $(4.42)$ & $(3.97)$ & $(6.95)$ & $(5.93)$ & $(5.71)$ & $(6.35)$ & $(3.84)$ & $(3.11)$ & $(7.89)$ & $(5.79)$ & $(0.62)$ \\
\hline NR Foreigners Total & $(17.59)$ & $(17.78)$ & $(18.04)$ & $(17.41)$ & $(16.81)$ & $(25.41)$ & $(16.93)$ & $(18.67)$ & $(19.06)$ & $(17.44)$ & $(16.26)$ & $(22.43)$ & $(24.37)$ & (4.98) \\
\hline
\end{tabular}


Table 4. Daily net buy proportions of various investors classes around firm-specific information days (12/2/96 11/30/98: 586 days)

For each type of investor, the daily net buy proportion is calculated as buy trade value minus sell trade value divided by the share value outstanding for the stockdays with at least one foreign trade and with a market model residual over 5\% in absolute values (excluding events with overlapping windows for a stock). The market model is estimated from Oct. 2, 1996 to Nov. 30, 1998, and daily closing prices falling below 1,000 won are treated as missing in calculating daily returns to minimize low-price effects. The reported value in each cell is the average across stocks on a day and then across days. NR stands for non-resident.

\begin{tabular}{|c|c|c|c|c|c|c|c|c|c|c|c|c|c|c|}
\hline Net Buy Proportion & D-5 & D-4 & D-3 & D-2 & D-1 & D0 & $\mathbf{D + 1}$ & $\mathbf{D + 2}$ & $\mathbf{D}+\mathbf{3}$ & $\mathrm{D}+4$ & \multicolumn{3}{|c|}{ D+5 Avg $(-5,-1) \operatorname{Avg}(+1,+5$} & Avg Diff \\
\hline Korean Individuals & 0.015 & 0.031 & 0.019 & 0.038 & 0.064 & 0.082 & 0.022 & 0.004 & 0.003 & 0.020 & 0.020 & 0.033 & 0.014 & 0.019 \\
\hline y managers & -0.015 & -0.019 & -0.009 & -0.013 & -0.029 & -0.036 & -0.015 & -0.002 & 0.001 & -0.010 & -0.012 & & -0.007 & -0.009 \\
\hline Korean Banks & -0.006 & -0.008 & -0.009 & -0.011 & -0.015 & -0.036 & -0.015 & -0.015 & -0.009 & -0.014 & -0.014 & 10 & -0.014 & 0.004 \\
\hline NR Foreign Individuals & 0.000 & 0.000 & 0.000 & 0.000 & -0.001 & 0.001 & 0.001 & 0.001 & 0.001 & 0.001 & 0.000 & 0.000 & 0.001 & -0.001 \\
\hline ey managers & 0.002 & -0.003 & 0.000 & -0.010 & -0.015 & 0.002 & 0.006 & 0.009 & 0.005 & 0.000 & 0.003 & & & -0.010 \\
\hline NR Forei & 0.000 & -0.001 & 0.000 & -0.001 & -0.001 & -0.001 & 0.000 & 0.001 & 0.000 & -0.001 & -0.001 & & 00 & 0.000 \\
\hline & 0.003 & -0.004 & 0.000 & -0.010 & -0.016 & 0.002 & 0.008 & 0.011 & 0.005 & 0.000 & 0.002 & -0.005 & 0.005 & -0.010 \\
\hline \multicolumn{15}{|c|}{ T-value for each trade proportion } \\
\hline Korean Individuals & $(2.79)$ & $(5.17)$ & $(3.60)$ & $(6.65)$ & $(8.40)$ & $(6.97)$ & $(2.70)$ & $(0.69)$ & $(0.42)$ & $(3.40)$ & $(3.65)$ & $(8.93)$ & $(3.34)$ & $(4.14)$ \\
\hline ley managers & $(-3.10)$ & $(-4.31)$ & $(-2.49)$ & $(-2.78)$ & $(-5.26)$ & $(-4.42)$ & $(-2.26)$ & $(-0.29)$ & $(0.12)$ & $(-2.25)$ & $(-2.52)$ & & & $(-2.78)$ \\
\hline & $(-3.05)$ & $(-3.34)$ & $(-3.90)$ & $(-4.75)$ & $(-4.86)$ & $(-8.45)$ & $(-4.12)$ & $(-4.39)$ & $(-4.03)$ & $(-4.52)$ & $(-4.01)$ & $(-7.37)$ & $(-7.25)$ & $(1.88)$ \\
\hline n Individuals & $(1.82)$ & $(0.17)$ & $(1.43)$ & $(0.82)$ & $(-0.77)$ & $(0.57)$ & $(1.78)$ & $(1.43)$ & $(1.62)$ & $(0.98)$ & $(-0.48)$ & $(0.08)$ & $(1.66)$ & $(-1.40)$ \\
\hline NR Forei & $(0.76)$ & $(-1.19)$ & $(-0.03)$ & $(-3.14)$ & $(-3.57)$ & $(0.42)$ & (1.41) & $(2.65)$ & $(1.60)$ & $(-0.13)$ & $(0.80)$ & $(-2.64)$ & $(1.92)$ & $(-3.76)$ \\
\hline NR Fore & $(0.25)$ & $(-1.37)$ & $(-0.31)$ & $(-1.16)$ & $(-1.01)$ & $(-0.33)$ & $(0.39)$ & (1.66) & $(-0.43)$ & $(-0.71)$ & $(-1.04)$ & $(-1.39)$ & $(-0.18)$ & $(-0.68)$ \\
\hline NR Foreigners Total & $(0.87)$ & $(-1.41)$ & $(0.02)$ & $(-3.23)$ & $(-3.78)$ & $(0.40)$ & $(1.70)$ & $(3.15)$ & $(1.66)$ & $(-0.07)$ & $(0.43)$ & $(-2.77)$ & $(2.09)$ & $(-3.92)$ \\
\hline
\end{tabular}


Table 4. (Continued)

Panel B. Net Buy proportion on Negative 5\% AR days (8.4 stocks per event of 529 days)

\begin{tabular}{|c|c|c|c|c|c|c|c|c|c|c|c|c|c|c|}
\hline Net Buy Proportion & D-5 & D-4 & D-3 & D-2 & D-1 & D0 & $\mathrm{D}+1$ & $\mathrm{D}+2$ & $\mathbf{D}+3$ & $\mathrm{D}+4$ & \multicolumn{3}{|c|}{ D+5 Avg $(-5,-1) \operatorname{Avg}(+1,+5$} & Avg Diff \\
\hline Korean Individuals & 0.027 & 0.035 & 0.032 & 0.043 & 0.025 & 0.113 & 0.091 & 0.052 & 0.054 & 0.046 & 0.036 & 0.032 & 0.052 & -0.020 \\
\hline Korean Money managers & -0.021 & -0.026 & -0.016 & -0.027 & -0.015 & -0.036 & -0.034 & -0.026 & -0.022 & -0.018 & -0.020 & -0.021 & -0.025 & 0.004 \\
\hline Korean Banks & -0.015 & -0.020 & -0.017 & -0.017 & -0.015 & -0.021 & -0.013 & -0.010 & -0.012 & -0.015 & -0.016 & -0.017 & -0.010 & -0.006 \\
\hline NR Foreign Individuals & 0.001 & 0.000 & 0.001 & 0.000 & 0.000 & -0.001 & -0.001 & 0.000 & 0.000 & 0.000 & 0.000 & 0.000 & 0.000 & 0.000 \\
\hline NR Foreign Money managers & 0.012 & 0.013 & 0.007 & 0.004 & 0.009 & -0.046 & -0.031 & -0.014 & -0.017 & -0.015 & -0.007 & 0.009 & -0.017 & 0.026 \\
\hline NR Foreign Banks & -0.001 & 0.000 & 0.000 & 0.000 & 0.000 & -0.003 & -0.002 & -0.001 & 0.001 & 0.001 & 0.001 & 0.000 & 0.002 & -0.002 \\
\hline NR Foreigners Total & 0.011 & 0.013 & 0.008 & 0.004 & 0.009 & -0.050 & -0.034 & -0.015 & -0.017 & -0.014 & -0.006 & 0.009 & -0.015 & 0.024 \\
\hline \multicolumn{15}{|c|}{ T-value for each trade proportion } \\
\hline Korean Individuals & $(2.64)$ & $(3.76)$ & $(3.71)$ & $(4.50)$ & $(2.36)$ & $(9.00)$ & $(7.76)$ & $(7.34)$ & $(6.31)$ & $(6.22)$ & $(5.36)$ & $(5.52)$ & $(8.74)$ & $(-2.78)$ \\
\hline Korean Money managers & $(-2.49)$ & $(-4.23)$ & $(-2.67)$ & $(-4.10)$ & $(-1.57)$ & $(-4.20)$ & $(-4.61)$ & $(-4.97)$ & $(-3.20)$ & $(-3.08)$ & $(-4.53)$ & $(-4.78)$ & $(-7.03)$ & $(0.79)$ \\
\hline Korean Banks & $(-4.23)$ & $(-3.73)$ & $(-4.35)$ & $(-3.93)$ & $(-3.10)$ & $(-4.28)$ & $(-4.26)$ & $(-3.65)$ & $(-3.75)$ & $(-3.22)$ & $(-5.05)$ & $(-6.63)$ & $(-5.67)$ & $(-2.22)$ \\
\hline NR Foreign Individuals & $(1.01)$ & $(-0.16)$ & $(1.68)$ & $(-0.39)$ & $(-0.11)$ & $(-0.45)$ & $(-1.03)$ & $(0.55)$ & $(-0.53)$ & $(-0.93)$ & $(-0.75)$ & $(0.49)$ & $(-0.28)$ & $(0.76)$ \\
\hline NR Foreign Money managers & $(2.38)$ & $(3.24)$ & $(1.73)$ & $(0.78)$ & $(1.58)$ & $(-6.37)$ & $(-6.18)$ & $(-3.36)$ & $(-3.43)$ & $(-4.12)$ & $(-1.94)$ & $(3.03)$ & $(-5.68)$ & $(7.39)$ \\
\hline NR Foreign Banks & $(-1.62)$ & $(0.65)$ & $(-0.43)$ & $(0.42)$ & $(-0.18)$ & $(-1.35)$ & $(-2.68)$ & $(-1.19)$ & $(0.75)$ & $(0.53)$ & $(0.51)$ & $(-0.68)$ & $(0.84)$ & $(-0.95)$ \\
\hline NR Foreigners Total & $(2.15)$ & $(3.23)$ & $(1.83)$ & $(0.74)$ & $(1.50)$ & $(-6.61)$ & $(-6.56)$ & $(-3.47)$ & $(-3.26)$ & $(-3.59)$ & $(-1.47)$ & $(2.90)$ & $(-4.28)$ & $(6.86)$ \\
\hline
\end{tabular}


Table 5. Intraday returns and volatility (\%) around 5-minute intervals of large price-setting order-imbalances

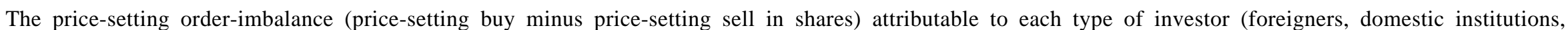

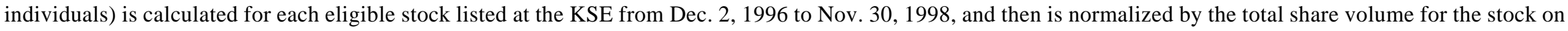

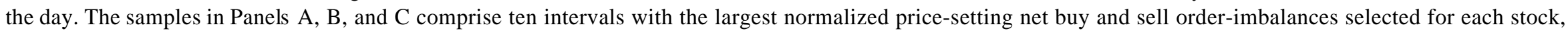

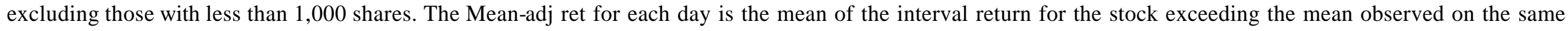

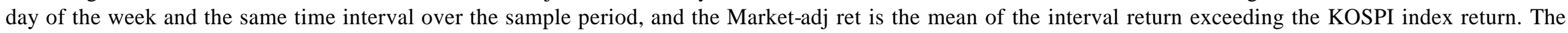

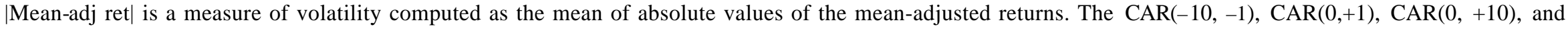

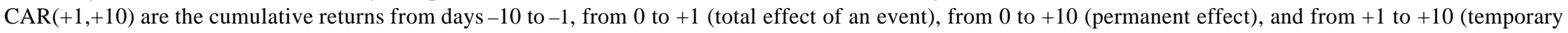

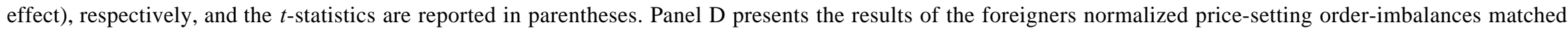
with the domestic institutions whose normalized order-imbalances are closest to the foreigners.

Panel A. Foreigners normalized price-setting order-imbalance events

\begin{tabular}{|c|c|c|c|c|c|c|c|c|c|c|c|c|c|c|}
\hline \multirow{3}{*}{$\begin{array}{l}\text { Event Interval } \\
\text { D-10 }\end{array}$} & \multicolumn{7}{|c|}{ Net Buy $(\mathrm{N}=4,110)$} & \multicolumn{7}{|c|}{ Net Sell $(\mathrm{N}=4,158)$} \\
\hline & \multicolumn{2}{|c|}{ Raw ret } & \multicolumn{2}{|c|}{ Mean-adj ret } & \multicolumn{3}{|c|}{$\begin{array}{l}\text { Cumulative } \mid \text { Mean-adj } \\
\text { mean-adj ret. }\end{array}$} & \multicolumn{2}{|c|}{ Raw ret } & \multicolumn{2}{|c|}{ Mean-adj ret } & \multicolumn{3}{|c|}{$\begin{array}{l}\text { Cumulative |Mean-adj } \\
\text { mean-adj ret. ret }\end{array}$} \\
\hline & -0.021 & $(-1.37)$ & -0.019 & $(-1.28)$ & -0.019 & $(-1.28)$ & 0.424 & -0.013 & $(-0.85)$ & -0.012 & $(-0.80)$ & -0.012 & $(-0.80)$ & 0.441 \\
\hline D-9 & 0.026 & (1.69) & 0.026 & $(1.72)$ & 0.007 & $(0.32)$ & 0.430 & -0.004 & $(-0.22)$ & -0.002 & $(-0.12)$ & -0.015 & $(-0.67)$ & 0.448 \\
\hline D-8 & 0.000 & $(0.02)$ & -0.001 & $(-0.06)$ & 0.006 & $(0.23)$ & 0.432 & -0.027 & $(-1.70)$ & -0.025 & $(-1.60)$ & -0.040 & $(-1.53)$ & 0.457 \\
\hline D-7 & 0.036 & $(2.37)$ & 0.038 & $(2.48)$ & 0.043 & (1.57) & 0.422 & 0.011 & $(0.67)$ & 0.011 & $(0.65)$ & -0.029 & $(-1.00)$ & 0.467 \\
\hline D-6 & 0.031 & (1.94) & 0.033 & $(2.07)$ & 0.076 & $(2.53)$ & 0.443 & 0.020 & $(1.23)$ & 0.019 & (1.18) & -0.009 & $(-0.30)$ & 0.454 \\
\hline D-5 & 0.032 & (1.96) & 0.031 & $(1.88)$ & 0.107 & $(3.21)$ & 0.461 & 0.025 & $(1.51)$ & 0.028 & $(1.70)$ & 0.019 & $(0.53)$ & 0.464 \\
\hline$D-4$ & 0.006 & $(0.35)$ & 0.006 & $(0.40)$ & 0.114 & $(3.25)$ & 0.445 & 0.061 & (3.29) & 0.058 & (3.16) & 0.077 & $(2.02)$ & 0.502 \\
\hline D-3 & 0.037 & $(2.23)$ & 0.038 & $(2.28)$ & 0.151 & (4.08) & 0.482 & 0.041 & (2.33) & 0.040 & $(2.26)$ & 0.117 & (2.89) & 0.482 \\
\hline D-2 & 0.043 & (2.20) & 0.045 & (2.29) & 0.196 & (4.97) & 0.547 & 0.002 & $(0.12)$ & 0.004 & $(0.23)$ & 0.121 & (2.87) & 0.522 \\
\hline D-1 & 0.115 & $(5.70)$ & 0.118 & (5.96) & 0.314 & $(7.42)$ & 0.587 & 0.014 & (0.68) & 0.016 & $(0.81)$ & 0.137 & (3.00) & 0.583 \\
\hline D 0 & 1.053 & $(30.20)$ & 1.041 & $(30.25)$ & 1.356 & $(26.75)$ & 1.378 & -0.738 & $(-23.85)$ & -0.730 & $(-23.78)$ & -0.592 & $(-11.23)$ & 1.182 \\
\hline $\mathrm{D}+1$ & 0.012 & $(0.61)$ & 0.013 & $(0.66)$ & 1.368 & $(27.22)$ & 0.570 & 0.270 & $(11.53)$ & 0.265 & $(11.47)$ & -0.327 & $(-6.21)$ & 0.636 \\
\hline$D+2$ & -0.017 & $(-0.86)$ & -0.013 & $(-0.67)$ & 1.355 & (26.48) & 0.580 & 0.124 & $(6.16)$ & 0.124 & $(6.23)$ & -0.203 & $(-3.84)$ & 0.572 \\
\hline$D+3$ & -0.058 & $(-3.30)$ & -0.061 & $(-3.47)$ & 1.294 & (24.99) & 0.524 & 0.069 & (3.86) & 0.066 & (3.68) & -0.137 & $(-2.57)$ & 0.533 \\
\hline $\mathrm{D}+4$ & -0.005 & $(-0.26)$ & -0.010 & $(-0.57)$ & 1.284 & (24.25) & 0.523 & 0.052 & (3.04) & 0.049 & (2.89) & -0.089 & $(-1.63)$ & 0.498 \\
\hline $\mathrm{D}+5$ & -0.021 & $(-1.19)$ & -0.023 & $(-1.29)$ & 1.261 & (23.44) & 0.510 & 0.007 & $(0.38)$ & 0.002 & (0.13) & -0.086 & $(-1.55)$ & 0.511 \\
\hline$D+6$ & -0.011 & $(-0.60)$ & -0.014 & $(-0.79)$ & 1.247 & (22.86) & 0.493 & 0.033 & (1.88) & 0.030 & (1.74) & -0.056 & $(-0.99)$ & 0.493 \\
\hline$D+7$ & -0.018 & $(-1.23)$ & -0.019 & $(-1.29)$ & 1.228 & (22.32) & 0.453 & 0.013 & $(0.77)$ & 0.012 & $(0.67)$ & -0.044 & $(-0.77)$ & 0.484 \\
\hline$D+8$ & -0.008 & $(-0.55)$ & -0.008 & $(-0.51)$ & 1.220 & (22.03) & 0.451 & 0.003 & $(0.18)$ & -0.002 & $(-0.16)$ & -0.047 & $(-0.80)$ & 0.440 \\
\hline $\mathrm{D}+9$ & -0.010 & $(-0.58)$ & -0.012 & $(-0.70)$ & 1.209 & (21.47) & 0.450 & 0.034 & $(2.20)$ & 0.033 & $(2.14)$ & -0.014 & $(-0.23)$ & 0.457 \\
\hline $\mathrm{D}+10$ & 0.005 & $(0.36)$ & 0.003 & $(0.19)$ & 1.212 & (21.06) & 0.442 & 0.016 & (0.99) & 0.016 & $(1.00)$ & 0.002 & $(0.03)$ & 0.449 \\
\hline$\overline{\mathrm{CAR}(-10,-1)}$ & 0.305 & $(7.13)$ & 0.314 & $(7.42)$ & & & & 0.132 & $(2.85)$ & 0.137 & $(3.00)$ & & & \\
\hline $\mathrm{CAR}(0,+1)$ & 1.065 & $(30.45)$ & 1.054 & $(30.60)$ & & & & -0.468 & $(-14.70)$ & -0.464 & $(-14.73)$ & & & \\
\hline $\operatorname{CAR}(0,+10)$ & 0.922 & $(20.30)$ & 0.897 & (19.93) & & & & -0.118 & $(-2.56)$ & -0.136 & $(-2.97)$ & & & \\
\hline $\operatorname{CAR}(+1,+10)$ & -0.131 & $(-2.96)$ & -0.144 & $(-3.26)$ & & & & 0.620 & (13.79) & 0.594 & (13.37) & & & \\
\hline
\end{tabular}


Table 5. (Continued)

Panel B. Domestic institutions normalized price-setting order-imbalance events

\begin{tabular}{|c|c|c|c|c|c|c|c|c|c|c|c|c|c|c|}
\hline \multirow{3}{*}{$\begin{array}{l}\text { Event Interval } \\
\text { D-10 }\end{array}$} & \multicolumn{7}{|c|}{ Net Buy $(\mathrm{N}=4,925)$} & \multicolumn{7}{|c|}{ Net Sell $(\mathrm{N}=4,967)$} \\
\hline & \multicolumn{2}{|c|}{ Raw ret } & \multicolumn{2}{|c|}{ Mean-adj ret } & \multicolumn{3}{|c|}{$\begin{array}{l}\text { Cumulative |Mean-adj } \\
\text { mean-adj ret. ret } \mid\end{array}$} & \multicolumn{2}{|c|}{ Raw ret } & \multicolumn{2}{|c|}{ Mean-adj ret } & \multicolumn{3}{|c|}{$\begin{array}{l}\text { Cumulative |Mean-adj } \\
\text { mean-adj ret. ret } \mid\end{array}$} \\
\hline & -0.024 & $(-1.76)$ & -0.024 & $(-1.80)$ & -0.024 & $(-1.80)$ & 0.384 & 0.019 & $(1.26)$ & 0.018 & $(1.20)$ & 0.018 & $(1.20)$ & 0.406 \\
\hline D-9 & -0.029 & $(-2.03)$ & -0.027 & $(-1.88)$ & -0.051 & $(-2.76)$ & 0.404 & 0.022 & (1.31) & 0.024 & $(1.47)$ & 0.042 & $(1.92)$ & 0.446 \\
\hline D-8 & -0.016 & $(-1.11)$ & -0.017 & $(-1.19)$ & -0.068 & $(-3.08)$ & 0.416 & 0.033 & $(2.16)$ & 0.035 & $(2.29)$ & 0.077 & (3.07) & 0.428 \\
\hline D-7 & -0.012 & $(-0.85)$ & -0.010 & $(-0.74)$ & -0.078 & $(-3.14)$ & 0.394 & 0.051 & (3.13) & 0.050 & $(3.10)$ & 0.127 & $(4.37)$ & 0.442 \\
\hline D-6 & -0.024 & $(-1.74)$ & -0.021 & $(-1.49)$ & -0.099 & $(-3.67)$ & 0.396 & 0.010 & $(0.64)$ & 0.014 & $(0.90)$ & 0.141 & $(4.46)$ & 0.442 \\
\hline D-5 & -0.019 & $(-1.29)$ & -0.021 & $(-1.43)$ & -0.119 & $(-4.06)$ & 0.415 & 0.046 & $(2.75)$ & 0.045 & (2.69) & 0.186 & (5.37) & 0.456 \\
\hline D-4 & -0.002 & $(-0.12)$ & 0.001 & $(0.09)$ & -0.118 & $(-3.77)$ & 0.409 & 0.061 & $(3.77)$ & 0.061 & $(3.82)$ & 0.247 & $(6.69)$ & 0.456 \\
\hline D-3 & 0.046 & $(2.96)$ & 0.044 & $(2.83)$ & -0.074 & $(-2.24)$ & 0.446 & 0.061 & $(3.60)$ & 0.061 & $(3.62)$ & 0.308 & (7.96) & 0.460 \\
\hline D-2 & 0.030 & (1.77) & 0.028 & $(1.71)$ & -0.046 & $(-1.28)$ & 0.489 & 0.088 & $(4.79)$ & 0.085 & (4.63) & 0.392 & (9.48) & 0.499 \\
\hline D-1 & 0.078 & $(4.02)$ & 0.079 & (4.09) & 0.033 & $(0.85)$ & 0.591 & 0.019 & $(0.94)$ & 0.022 & (1.13) & 0.415 & $(9.28)$ & 0.546 \\
\hline $\mathrm{D} 0$ & 1.237 & $(34.05)$ & 1.220 & $(33.93)$ & 1.253 & (25.56) & 1.686 & -0.942 & $(-25.81)$ & -0.933 & $(-25.80)$ & -0.518 & $(-9.55)$ & 1.484 \\
\hline $\mathrm{D}+1$ & 0.125 & $(5.44)$ & 0.121 & $(5.29)$ & 1.374 & $(28.13)$ & 0.693 & 0.306 & $(12.05)$ & 0.298 & $(11.88)$ & -0.220 & $(-4.05)$ & 0.728 \\
\hline$D+2$ & -0.056 & $(-2.52)$ & -0.052 & $(-2.38)$ & 1.322 & (26.76) & 0.682 & 0.186 & (8.64) & 0.186 & $(8.67)$ & -0.034 & $(-0.63)$ & 0.608 \\
\hline$D+3$ & -0.047 & $(-2.41)$ & -0.056 & $(-2.93)$ & 1.266 & (25.16) & 0.582 & 0.119 & $(6.75)$ & 0.117 & (6.66) & 0.083 & $(1.52)$ & 0.523 \\
\hline$D+4$ & -0.048 & $(-2.42)$ & -0.058 & $(-2.97)$ & 1.208 & (23.37) & 0.558 & 0.078 & (4.42) & 0.075 & $(4.25)$ & 0.158 & (2.84) & 0.506 \\
\hline$D+5$ & -0.067 & $(-3.61)$ & -0.071 & $(-3.86)$ & 1.137 & (21.66) & 0.525 & 0.067 & (3.93) & 0.059 & $(3.46)$ & 0.216 & (3.88) & 0.459 \\
\hline$D+6$ & -0.023 & $(-1.26)$ & -0.024 & $(-1.35)$ & 1.113 & (20.80) & 0.489 & 0.025 & (1.65) & 0.023 & $(1.52)$ & 0.240 & $(4.26)$ & 0.446 \\
\hline$D+7$ & -0.053 & $(-3.19)$ & -0.057 & $(-3.45)$ & 1.056 & (19.58) & 0.466 & 0.051 & (3.17) & 0.046 & (2.91) & 0.286 & $(5.00)$ & 0.453 \\
\hline $\mathrm{D}+8$ & -0.046 & $(-2.83)$ & -0.048 & $(-2.98)$ & 1.008 & (18.52) & 0.452 & 0.044 & $(2.73)$ & 0.039 & $(2.45)$ & 0.325 & (5.63) & 0.446 \\
\hline $\mathrm{D}+9$ & 0.007 & $(0.44)$ & 0.004 & $(0.24)$ & 1.012 & (18.53) & 0.445 & 0.004 & $(0.28)$ & 0.001 & $(0.06)$ & 0.326 & $(5.61)$ & 0.438 \\
\hline $\mathrm{D}+10$ & -0.026 & $(-1.71)$ & -0.028 & $(-1.86)$ & 0.983 & $(17.81)$ & 0.430 & 0.008 & $(0.51)$ & 0.004 & $(0.24)$ & 0.330 & $(5.59)$ & 0.458 \\
\hline $\mathrm{CAR}(-10,-1)$ & 0.028 & $(0.72)$ & 0.033 & $(0.85)$ & & & & 0.409 & $(9.09)$ & 0.415 & $(9.28)$ & & & \\
\hline $\mathrm{CAR}(0,+1)$ & 1.362 & $(36.49)$ & 1.341 & (36.28) & & & & -0.637 & $(-17.34)$ & -0.634 & $(-17.47)$ & & & \\
\hline $\mathrm{CAR}(0,+10)$ & 1.004 & (21.40) & 0.950 & (20.49) & & & & -0.053 & $(-1.19)$ & -0.085 & $(-1.93)$ & & & \\
\hline $\operatorname{CAR}(+1,+10)$ & -0.233 & $(-5.04)$ & -0.270 & $(-5.90)$ & & & & 0.889 & (19.67) & 0.848 & (18.93) & & & \\
\hline
\end{tabular}


Table 5. (Continued)

Panel C. Foreigners normalized price-setting order-imbalances matched with domestic institutions

\begin{tabular}{|c|c|c|c|c|c|c|c|c|c|c|c|c|c|c|c|c|c|c|}
\hline \multirow{3}{*}{$\begin{array}{l}\text { Event Interval } \\
\text { D-10 }\end{array}$} & \multicolumn{10}{|c|}{ Net Buy $(\mathrm{N}=4,026)$} & \multicolumn{8}{|c|}{ Net Sell $(\mathrm{N}=4,097)$} \\
\hline & \multicolumn{2}{|c|}{$\begin{array}{r}\text { Foreigner } \\
\text { Mean-Adj Ret } \\
\end{array}$} & \multicolumn{2}{|c|}{$\begin{array}{r}\text { Institution } \\
\text { Mean-Adj Ret } \\
\end{array}$} & \multicolumn{2}{|c|}{ Difference } & \multicolumn{2}{|c|}{$\begin{array}{c}\text { Cumulative } \\
\text { Difference } \\
\end{array}$} & \multicolumn{2}{|c|}{$\begin{array}{c}\text { Difference in } \\
\text { |Mean-Adj Ret| }\end{array}$} & $\begin{array}{r}\text { Foreigner } \\
\text { Mean-Adj Ret } \\
\end{array}$ & \multicolumn{2}{|c|}{$\begin{array}{r}\text { Institution } \\
\text { Mean-Adj Ret } \\
\end{array}$} & \multicolumn{2}{|c|}{ Difference } & \multicolumn{2}{|c|}{$\begin{array}{r}\text { Cumulative } \\
\text { Difference } \\
\end{array}$} & $\begin{array}{r}\text { Difference in } \\
\text { |Mean-Adj Ret } \mid\end{array}$ \\
\hline & -0.020 & $(-1.31)$ & 0.000 & $(0.02)$ & -0.020 & $(-0.96)$ & -0.020 & $(-0.96)$ & 0.015 & $(0.82)$ & $-0.012(-0.77)$ & 0.002 & $(0.15)$ & -0.015 & $(-0.64)$ & -0.015 & $(-0.64)$ & $-0.007 \quad(-0.35)$ \\
\hline D-9 & 0.029 & $(1.93)$ & 0.005 & $(0.36)$ & 0.024 & (1.13) & 0.003 & $(0.12)$ & 0.016 & $(0.85)$ & $-0.002(-0.14)$ & 0.003 & $(0.21)$ & -0.006 & $(-0.24)$ & -0.020 & $(-0.65)$ & 0.019 \\
\hline D-8 & 0.001 & $(0.06)$ & -0.001 & $(-0.08)$ & 0.002 & $(0.10)$ & 0.005 & $(0.16)$ & 0.013 & $(0.67)$ & $-0.026(-1.61)$ & 0.050 & $(3.17)$ & -0.076 & $(-3.40)$ & -0.096 & $(-2.60)$ & $-0.002(-0.11)$ \\
\hline D-7 & 0.039 & $(2.54)$ & -0.014 & $(-0.91)$ & 0.052 & $(2.43)$ & 0.058 & $(1.50)$ & 0.001 & $(0.03)$ & $0.008 \quad(0.48)$ & 0.059 & $(3.50)$ & -0.051 & $(-2.13)$ & -0.147 & $(-3.52)$ & $-0.004 \quad(-0.18)$ \\
\hline D-6 & 0.030 & $(1.90)$ & 0.009 & $(0.65)$ & 0.021 & $(0.97)$ & 0.079 & $(1.92)$ & 0.025 & & 0.019 & 0.017 & $(1.00)$ & 0.002 & $(0.10)$ & -0.145 & $3.14)$ & $-0.013 \quad(-0$ \\
\hline D-5 & 0.029 & (1.78) & 0.004 & $(0.27)$ & 0.025 & $(1.10)$ & 0.104 & $(2.31)$ & 0.020 & $(0.96)$ & 0.027 & 0.067 & $(3.76)$ & -0.040 & $(-1.63)$ & -0.185 & 3.66) & $-0.036(-1.64)$ \\
\hline D-4 & 0.003 & $(0.18)$ & 0.008 & $(0.55)$ & -0.006 & $(-0.25)$ & 0.098 & $(2.07)$ & -0.010 & $(-0.51)$ & $(3.25)$ & 0.052 & (2.99) & 0.009 & $(0.35)$ & -0.176 & $(-3.23)$ & $0.011 \quad(0.48)$ \\
\hline D-3 & 0.038 & $(2.30)$ & 0.036 & $(2.29)$ & 0.002 & $(0.09)$ & 0.101 & (1.99) & 0.017 & $(0.85)$ & $(2.20)$ & 0.050 & $(2.62)$ & -0.012 & $(-0.48)$ & -0.188 & $(-3.29)$ & $-0.057(-2.44)$ \\
\hline D-2 & 0.045 & $(2.29)$ & 0.058 & (3.13) & -0.013 & $(-0.48)$ & 0.088 & (1.60) & -0.002 & $(-0.07)$ & $0.000 \quad(-0.02)$ & 0.081 & (3.89) & -0.081 & $(-2.95)$ & -0.269 & $(-4.49)$ & $-0.030 \quad(-1.17)$ \\
\hline D-1 & 0.117 & $(5.80)$ & 0.157 & $(7.75)$ & -0.040 & $(-1.40)$ & 0.047 & $(0.79)$ & -0.011 & $(-0.44)$ & $0.007 \quad(0.35)$ & 0.043 & $(2.32)$ & -0.036 & $(-1.33)$ & -0.305 & $(-4.73)$ & $0.036 \quad(1.49)$ \\
\hline D 0 & 1.028 & $(30.04)$ & 0.997 & $(31.66)$ & 0.030 & $(0.66)$ & 0.078 & $(1.11)$ & 0.032 & $(0.78)$ & $-0.728(24.09)$ & -0.720 & $(-23.0)$ & -0.008 & $(-0.18)$ & -0.313 & $(-4.23)$ & 0.023 \\
\hline $\mathrm{D}+1$ & 0.017 & $(0.88)$ & 0.154 & $(6.60)$ & -0.137 & $(-4.51)$ & -0.059 & $(-0.83)$ & -0.098 & & $0.257(11.27)$ & 0.144 & $(7.19)$ & 0.113 & & -0.200 & & 0.055 \\
\hline $\mathrm{D}+2$ & -0.017 & $(-0.84)$ & -0.041 & $(-1.86)$ & 0.024 & $(0.81)$ & -0.035 & $(-0.48)$ & -0.059 & $(-2.23)$ & $0.122 \quad(6.07)$ & 0.131 & $(6.88)$ & -0.010 & $(-0$ & -0.210 & 82) & 0.024 \\
\hline$D+3$ & -0.055 & $(-3.13)$ & -0.079 & $(-4.12)$ & 0.024 & $(0.92)$ & -0.011 & $(-0.15)$ & -0.053 & $(-2.29)$ & $(3.68)$ & 0.082 & (4.27) & -0.016 & $(-0.59)$ & -0.226 & $(-3.00)$ & $-0.003 \quad(-0.14)$ \\
\hline $\mathrm{D}+4$ & -0.009 & $(-0.49)$ & -0.072 & $(-3.99)$ & 0.064 & $(2.50)$ & 0.053 & $(0.69)$ & -0.008 & $(-0.34)$ & 0.048 & 0.034 & (1.94) & 0.014 & $(0.55)$ & -0.212 & $(-2.78)$ & $-0.020 \quad(-0.91)$ \\
\hline $\mathrm{D}+5$ & -0.025 & $(-1.42)$ & -0.030 & $(-1.67)$ & 0.005 & $(0.19)$ & 0.057 & $(0.75)$ & 0.005 & $(0.21)$ & $(0.08)$ & 0.004 & $(0.25)$ & -0.002 & $(-0.10)$ & -0.215 & $(-2.75)$ & $0.054 \quad(2.52)$ \\
\hline $\mathrm{D}+6$ & -0.017 & $(-1.00)$ & -0.002 & $(-0.09)$ & -0.016 & $(-0.55)$ & 0.042 & $(0.52)$ & -0.049 & $(-1.90)$ & $(1.74)$ & 0.050 & $(3.16)$ & -0.019 & $(-0.82)$ & -0.234 & $(-2.96)$ & 0.035 \\
\hline $\mathrm{D}+7$ & -0.018 & $(-1.20)$ & 0.001 & $(0.06)$ & -0.019 & $(-0.86)$ & 0.023 & $(0.28)$ & -0.020 & $(-0.98)$ & $(0.89)$ & 0.007 & $(0.43)$ & 0.008 & $(0.35)$ & -0.225 & $(-2.78)$ & 0.023 \\
\hline $\mathrm{D}+8$ & -0.003 & $(-0.17)$ & -0.014 & $(-0.82)$ & 0.011 & $(0.49)$ & 0.034 & $(0.42)$ & -0.013 & $(-0.61)$ & $-0.003 \quad(-0.19)$ & 0.059 & $(3.67)$ & -0.062 & $(-2.81)$ & -0.287 & $(-3.50)$ & $-0.022 \quad(-1.14)$ \\
\hline $\mathrm{D}+9$ & -0.014 & $(-0.83)$ & -0.018 & $(-1.10)$ & 0.005 & $(0.19)$ & 0.038 & $(0.47)$ & -0.014 & $(-0.65)$ & $0.030 \quad(1.98)$ & 0.012 & $(0.76)$ & 0.018 & $(0.79)$ & -0.270 & $(-3.23)$ & $-0.005 \quad(-0.25)$ \\
\hline $\mathrm{D}+10$ & 0.003 & $(0.21)$ & -0.036 & $(-2.31)$ & 0.039 & $(1.81)$ & 0.078 & $(0.94)$ & -0.009 & $(-0.47)$ & $(1.15)$ & 0.024 & $(1.36)$ & -0.006 & $(-0.24)$ & -0.275 & $(-3.25)$ & $-0.042 \quad(-2.01)$ \\
\hline $\operatorname{CAR}(-10,-1)$ & 0.312 & $(7.31)$ & 0.264 & $(6.35)$ & 0.047 & $(0.79)$ & & & & & $0.119 \quad(2.60)$ & 0.424 & $(9.22)$ & -0.305 & $(-4.73)$ & & & \\
\hline $\operatorname{CAR}(0,+1)$ & 1.045 & $(30.37)$ & 1.151 & $(33.62)$ & -0.106 & $(-2.19)$ & & & & & $-0.471(15.07)$ & -0.576 & $(-17.5)$ & 0.105 & $(2.28)$ & & & \\
\hline $\operatorname{CAR}(0,+10)$ & 0.890 & (19.76) & 0.859 & (17.64) & 0.030 & $(0.45)$ & & & & & $-0.143(-3.13)$ & -0.173 & $(-3.88)$ & 0.030 & $(0.47)$ & & & \\
\hline CAR $(+1,+10)$ & -0.138 & $(-3.11)$ & -0.138 & $(-2.90)$ & 0.000 & $(0.00)$ & & & & & $0.585(13.12)$ & 0.547 & (12.91) & 0.038 & $(0.63)$ & & & \\
\hline
\end{tabular}


Table 5. (Continued)

Panel D. Domestic individuals normalized price-setting order-imbalance events

\begin{tabular}{|c|c|c|c|c|c|c|c|c|c|c|c|c|c|c|}
\hline \multirow{3}{*}{$\begin{array}{c}\text { Event Interval } \\
\text { D-10 }\end{array}$} & \multicolumn{7}{|c|}{ Net Buy $(\mathrm{N}=5,046)$} & \multicolumn{7}{|c|}{ Net Sell $(\mathrm{N}=5,040)$} \\
\hline & \multicolumn{2}{|c|}{ Raw ret } & \multicolumn{2}{|c|}{ Mean-adj ret } & \multicolumn{3}{|c|}{$\begin{array}{c}\text { Cumulative |Mean-adj } \\
\text { mean-adj ret. ret } \mid\end{array}$} & \multicolumn{2}{|c|}{ Raw ret } & \multicolumn{2}{|c|}{ Mean-adj ret } & \multicolumn{3}{|c|}{$\begin{array}{l}\text { Cumulative } \mid \text { Mean-adj } \\
\text { mean-adj ret. ret } \mid\end{array}$} \\
\hline & -0.053 & $(-3.23)$ & -0.052 & $(-3.16)$ & -0.052 & $(-3.16)$ & 0.406 & 0.009 & $(0.61)$ & 0.011 & $(0.80)$ & 0.011 & $(0.80)$ & 0.369 \\
\hline D-9 & -0.032 & $(-1.87)$ & -0.030 & $(-1.79)$ & -0.082 & $(-3.60)$ & 0.394 & 0.013 & $(0.87)$ & 0.017 & (1.12) & 0.028 & (1.40) & 0.382 \\
\hline D-8 & -0.029 & $(-1.69)$ & -0.030 & $(-1.75)$ & -0.112 & $(-4.13)$ & 0.417 & 0.012 & $(0.87)$ & 0.017 & $(1.23)$ & 0.045 & (1.92) & 0.366 \\
\hline D-7 & -0.044 & $(-2.89)$ & -0.044 & $(-2.91)$ & -0.156 & $(-5.21)$ & 0.367 & 0.021 & $(1.40)$ & 0.023 & (1.53) & 0.068 & $(2.50)$ & 0.388 \\
\hline D-6 & -0.067 & $(-4.06)$ & -0.066 & $(-4.02)$ & -0.222 & $(-6.76)$ & 0.402 & 0.010 & $(0.70)$ & 0.013 & $(0.90)$ & 0.081 & $(2.75)$ & 0.384 \\
\hline D-5 & -0.045 & $(-2.63)$ & -0.045 & $(-2.65)$ & -0.267 & $(-7.43)$ & 0.402 & 0.032 & (2.07) & 0.035 & $(2.29)$ & 0.116 & (3.59) & 0.380 \\
\hline D-4 & -0.024 & $(-1.29)$ & -0.025 & $(-1.37)$ & -0.293 & $(-7.46)$ & 0.439 & 0.019 & (1.14) & 0.019 & (1.16) & 0.135 & (3.84) & 0.398 \\
\hline D-3 & -0.018 & $(-0.97)$ & -0.019 & $(-1.01)$ & -0.311 & $(-7.48)$ & 0.445 & 0.045 & $(2.72)$ & 0.048 & $(2.92)$ & 0.183 & (4.82) & 0.417 \\
\hline D-2 & -0.027 & $(-1.29)$ & -0.030 & $(-1.41)$ & -0.341 & $(-7.53)$ & 0.530 & 0.038 & (2.07) & 0.037 & (2.03) & 0.220 & (5.28) & 0.465 \\
\hline D-1 & -0.009 & $(-0.34)$ & -0.012 & $(-0.50)$ & -0.353 & $(-6.94)$ & 0.674 & 0.027 & (1.11) & 0.025 & (1.06) & 0.245 & $(5.22)$ & 0.625 \\
\hline $\mathrm{D} 0$ & 1.233 & $(28.64)$ & 1.212 & $(28.38)$ & 0.859 & $(13.30)$ & 1.804 & -0.950 & $(-25.67)$ & -0.945 & $(-25.85)$ & -0.700 & $(-12.06)$ & 1.527 \\
\hline $\mathrm{D}+1$ & 0.244 & $(8.10)$ & 0.236 & $(7.91)$ & 1.095 & (16.98) & 0.862 & 0.201 & $(8.75)$ & 0.196 & $(8.59)$ & -0.504 & $(-8.68)$ & 0.624 \\
\hline $\mathrm{D}+2$ & -0.106 & $(-4.03)$ & -0.106 & $(-4.06)$ & 0.989 & $(14.92)$ & 0.741 & 0.127 & (5.89) & 0.127 & $(5.95)$ & -0.376 & $(-6.44)$ & 0.568 \\
\hline$D+3$ & -0.081 & $(-3.29)$ & -0.090 & $(-3.69)$ & 0.899 & (13.44) & 0.658 & 0.055 & (2.74) & 0.046 & (2.36) & -0.330 & $(-5.53)$ & 0.513 \\
\hline$D+4$ & -0.044 & $(-1.96)$ & -0.052 & $(-2.34)$ & 0.847 & $(12.55)$ & 0.589 & 0.047 & $(2.60)$ & 0.038 & (2.08) & -0.292 & $(-4.87)$ & 0.474 \\
\hline$D+5$ & -0.037 & $(-1.75)$ & -0.042 & $(-2.02)$ & 0.805 & (11.74) & 0.551 & 0.051 & (2.62) & 0.042 & (2.17) & -0.251 & $(-4.15)$ & 0.484 \\
\hline$D+6$ & -0.026 & $(-1.27)$ & -0.031 & $(-1.57)$ & 0.773 & (11.12) & 0.524 & -0.027 & $(-1.62)$ & -0.029 & $(-1.69)$ & -0.279 & $(-4.57)$ & 0.447 \\
\hline$D+7$ & -0.029 & $(-1.41)$ & -0.035 & $(-1.73)$ & 0.739 & $(10.52)$ & 0.528 & 0.001 & $(0.05)$ & -0.003 & $(-0.18)$ & -0.282 & $(-4.55)$ & 0.427 \\
\hline$D+8$ & 0.006 & $(0.28)$ & 0.003 & $(0.13)$ & 0.741 & $(10.45)$ & 0.540 & 0.062 & $(3.70)$ & 0.057 & $(3.44)$ & -0.225 & $(-3.60)$ & 0.412 \\
\hline $\mathrm{D}+9$ & 0.033 & $(1.55)$ & 0.029 & (1.41) & 0.771 & (10.69) & 0.523 & 0.019 & $(1.08)$ & 0.017 & $(0.99)$ & -0.208 & $(-3.32)$ & 0.410 \\
\hline $\mathrm{D}+10$ & 0.031 & (1.67) & 0.026 & $(1.40)$ & 0.797 & (10.91) & 0.477 & 0.002 & $(0.11)$ & -0.003 & $(-0.18)$ & -0.211 & $(-3.33)$ & 0.376 \\
\hline $\operatorname{CAR}(-10,-1)$ & -0.347 & $(-6.77)$ & -0.353 & $(-6.94)$ & & & & 0.226 & $(4.76)$ & 0.245 & $(5.22)$ & & & \\
\hline $\mathrm{CAR}(0,+1)$ & 1.477 & (32.79) & 1.448 & (32.41) & & & & -0.749 & $(-19.65)$ & -0.749 & $(-19.93)$ & & & \\
\hline $\operatorname{CAR}(0,+10)$ & 1.225 & (20.99) & 1.150 & (19.86) & & & & -0.414 & $(-8.73)$ & -0.456 & $(-9.76)$ & & & \\
\hline $\operatorname{CAR}(+1,+10)$ & -0.008 & $(-0.15)$ & -0.062 & $(-1.18)$ & & & & 0.536 & $(12.65)$ & 0.488 & (11.59) & & & \\
\hline
\end{tabular}




\section{Table 6. Daily returns and volatility $(\%)$ around days of large order-imbalances}

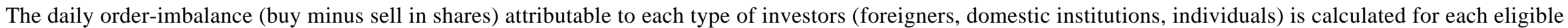

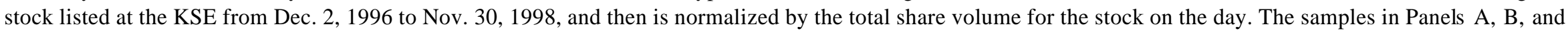

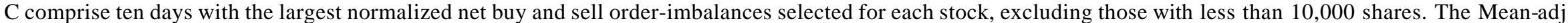

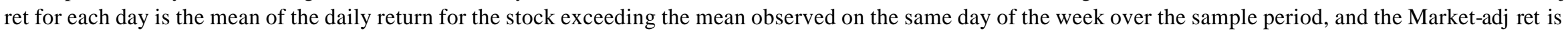
the mean of the daily return exceeding the KOSPI index return. The |Mean-adj ret| is a measure of volatility computed as the mean of absolute values of the mean-

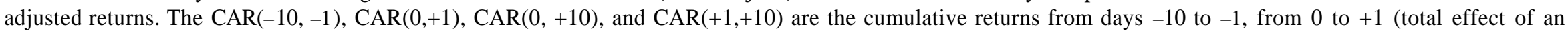
event), from 0 to +10 (permanent effect), and from +1 to +10 (temporary effect), respectively, and the $t$-statistics are reported in parentheses. Panel $\mathrm{D}$ presents the results of the foreigners normalized order-imbalances matched with the domestic institutions whose normalized order-imbalances are closest to the foreigners.

Panel A. Foreigners normalized order-imbalance events

\begin{tabular}{|c|c|c|c|c|c|c|c|c|c|c|c|c|c|c|}
\hline \multirow{3}{*}{$\begin{array}{c}\text { Event Day } \\
\text { D-10 }\end{array}$} & \multicolumn{7}{|c|}{ Net Buy $(\mathrm{N}=1,552)$} & \multicolumn{7}{|c|}{ Net Sell $(\mathrm{N}=1,661)$} \\
\hline & \multicolumn{2}{|c|}{ Raw ret } & \multicolumn{2}{|c|}{ Mean-adj ret } & \multicolumn{3}{|c|}{$\begin{array}{c}\text { Market-adj ret |Mean-adj } \\
\text { ret } \mid\end{array}$} & \multicolumn{2}{|c|}{ Raw ret } & \multicolumn{2}{|c|}{ Mean-adj ret } & \multicolumn{3}{|c|}{$\begin{array}{c}\text { Market-adj ret|Mean-adj } \\
\text { ret| }\end{array}$} \\
\hline & 0.105 & $(1.00)$ & 0.171 & $(1.63)$ & 0.010 & $(0.11)$ & 3.135 & $\begin{array}{l}-0.179 \\
\end{array}$ & $\begin{array}{c}(-1.77) \\
(-1)\end{array}$ & -0.084 & $(-0.82)$ & -0.017 & $(-0.19)$ & 3.094 \\
\hline D-9 & -0.017 & $(-0.17)$ & 0.050 & $(0.47)$ & 0.029 & $(0.32)$ & 3.183 & -0.281 & $(-2.72)$ & -0.186 & $(-1.78)$ & -0.130 & $(-1.47)$ & 3.199 \\
\hline D-8 & -0.039 & $(-0.38)$ & 0.030 & $(0.28)$ & 0.082 & $(0.93)$ & 3.108 & -0.221 & $(-2.17)$ & -0.125 & $(-1.21)$ & -0.103 & $(-1.21)$ & 3.215 \\
\hline D-7 & 0.064 & $(0.62)$ & 0.133 & $(1.28)$ & 0.096 & $(1.11)$ & 3.045 & -0.102 & $(-0.98)$ & -0.006 & $(-0.05)$ & -0.088 & $(-0.97)$ & 3.244 \\
\hline D-6 & 0.149 & $(1.40)$ & 0.217 & $(2.04)$ & 0.106 & (1.19) & 3.170 & -0.368 & $(-3.58)$ & -0.272 & $(-2.65)$ & -0.132 & $(-1.53)$ & 3.191 \\
\hline D-5 & 0.251 & $(2.42)$ & 0.320 & $(3.06)$ & 0.278 & (3.14) & 3.092 & -0.391 & $(-3.71)$ & -0.297 & $(-2.79)$ & -0.133 & $(-1.51)$ & 3.318 \\
\hline $\mathrm{D}-4$ & 0.245 & (2.33) & 0.314 & $(2.96)$ & 0.366 & (3.98) & 3.145 & -0.232 & $(-2.23)$ & -0.135 & $(-1.29)$ & -0.161 & $(-1.84)$ & 3.225 \\
\hline D-3 & 0.052 & $(0.51)$ & 0.123 & $(1.20)$ & 0.233 & (2.61) & 3.044 & -0.437 & $(-4.10)$ & -0.338 & $(-3.17)$ & -0.177 & $(-1.96)$ & 3.282 \\
\hline D-2 & 0.444 & $(4.27)$ & 0.514 & $(4.90)$ & 0.498 & $(5.47)$ & 3.103 & -0.560 & $(-5.07)$ & -0.461 & $(-4.16)$ & -0.240 & $(-2.75)$ & 3.440 \\
\hline $\mathrm{D}-1$ & 0.581 & $(5.52)$ & 0.649 & $(6.16)$ & 0.598 & $(6.65)$ & 3.170 & -0.427 & $(-3.75)$ & -0.329 & $(-2.88)$ & -0.308 & $(-3.20)$ & 3.636 \\
\hline $\mathrm{D} 0$ & 1.203 & $(11.41)$ & 1.271 & $(12.14)$ & 1.582 & $(16.71)$ & 3.232 & -0.240 & $(-2.04)$ & -0.144 & $(-1.22)$ & -0.481 & $(-4.57)$ & 3.762 \\
\hline$\overline{D+1}$ & -0.029 & $(-0.27)$ & 0.040 & $(0.38)$ & -0.015 & $(-0.16)$ & 3.113 & 0.413 & $(3.76)$ & 0.510 & $(4.62)$ & 0.438 & $(4.46)$ & 3.485 \\
\hline $\mathrm{D}+2$ & 0.001 & $(0.01)$ & 0.069 & (0.67) & -0.198 & $(-2.22)$ & 3.065 & -0.147 & $(-1.37)$ & -0.050 & $(-0.46)$ & 0.012 & $(0.13)$ & 3.377 \\
\hline $\mathrm{D}+3$ & -0.309 & $(-3.03)$ & -0.242 & $(-2.35)$ & -0.353 & $(-4.04)$ & 3.052 & -0.200 & $(-1.89)$ & -0.104 & $(-0.97)$ & -0.029 & $(-0.34)$ & 3.300 \\
\hline $\mathrm{D}+4$ & -0.185 & $(-1.80)$ & -0.117 & $(-1.13)$ & -0.016 & $(-0.18)$ & 3.033 & -0.105 & $(-1.01)$ & -0.008 & $(-0.08)$ & 0.051 & $(0.57)$ & 3.246 \\
\hline $\mathrm{D}+5$ & -0.193 & $(-1.87)$ & -0.125 & $(-1.20)$ & -0.193 & $(-2.21)$ & 3.070 & -0.232 & $(-2.19)$ & -0.136 & $(-1.28)$ & -0.056 & $(-0.63)$ & 3.332 \\
\hline $\mathrm{D}+6$ & 0.040 & $(0.41)$ & 0.108 & $(1.10)$ & -0.002 & $(-0.02)$ & 2.836 & -0.355 & $(-3.33)$ & -0.260 & $(-2.46)$ & -0.076 & $(-0.86)$ & 3.250 \\
\hline $\mathrm{D}+7$ & -0.175 & $(-1.74)$ & -0.106 & $(-1.04)$ & -0.154 & $(-1.75)$ & 2.974 & -0.238 & $(-2.22)$ & -0.143 & $(-1.32)$ & -0.020 & $(-0.23)$ & 3.352 \\
\hline $\mathrm{D}+8$ & -0.229 & $(-2.34)$ & -0.160 & $(-1.61)$ & -0.101 & $(-1.20)$ & 2.923 & -0.207 & $(-1.99)$ & -0.110 & $(-1.05)$ & -0.002 & $(-0.02)$ & 3.231 \\
\hline $\mathrm{D}+9$ & -0.025 & $(-0.24)$ & 0.044 & $(0.42)$ & -0.061 & $(-0.67)$ & 3.074 & -0.191 & $(-1.75)$ & -0.095 & $(-0.87)$ & -0.115 & $(-1.29)$ & 3.408 \\
\hline $\mathrm{D}+10$ & -0.119 & $(-1.18)$ & -0.049 & $(-0.49)$ & -0.047 & $(-0.55)$ & 2.971 & -0.051 & $(-0.47)$ & 0.045 & $(0.41)$ & -0.088 & $(-0.99)$ & 3.435 \\
\hline $\operatorname{CAR}(-10,-1)$ & 1.827 & $(4.98)$ & 2.508 & $(6.59)$ & 2.285 & $(7.65)$ & & -3.175 & $(-8.25)$ & -2.215 & $(-5.51)$ & -1.478 & $(-4.71)$ & \\
\hline $\mathrm{CAR}(0,+1)$ & 1.174 & $(7.48)$ & 1.311 & $(8.36)$ & 1.567 & (11.33) & & 0.173 & $(1.02)$ & 0.366 & $(2.15)$ & -0.044 & $(-0.30)$ & \\
\hline $\operatorname{CAR}(0,+10)$ & -0.012 & $(-0.03)$ & 0.738 & (1.92) & 0.451 & (1.48) & & -1.544 & $(-4.00)$ & -0.491 & $(-1.21)$ & -0.366 & $(-1.16)$ & \\
\hline $\mathrm{CAR}(+1,+10)$ & -1.215 & $(-3.50)$ & -0.533 & $(-1.46)$ & -1.131 & $(-3.95)$ & & -1.304 & $(-3.57)$ & -0.347 & $(-0.90)$ & 0.115 & $(0.38)$ & \\
\hline
\end{tabular}


Table 6. (Continued)

Panel B. Domestic institutions normalized order-imbalance events

\begin{tabular}{|c|c|c|c|c|c|c|c|c|c|c|c|c|c|}
\hline \multirow{3}{*}{$\begin{array}{c}\text { Event Day } \\
\text { D-10 }\end{array}$} & \multicolumn{7}{|c|}{ Net Buy $(\mathrm{N}=2,155)$} & \multicolumn{6}{|c|}{ Net Sell $(\mathrm{N}=2,331)$} \\
\hline & \multicolumn{2}{|c|}{ Raw ret } & \multicolumn{2}{|c|}{ Mean-adj ret } & \multicolumn{3}{|c|}{$\begin{array}{r}\text { Market-adj ret |Mean-adj } \\
\text { ret| }\end{array}$} & \multicolumn{2}{|c|}{ Raw ret } & \multicolumn{2}{|c|}{ Mean-adj ret } & \multicolumn{2}{|c|}{$\begin{array}{c}\text { Market-adj ret|Mean-adj } \\
\text { ret| }\end{array}$} \\
\hline & -0.208 & $(-2.37)$ & -0.103 & $(-1.17)$ & 0.003 & $(0.04)$ & 3.056 & -0.417 & $(-4.29)$ & -0.343 & $(-3.51)$ & $-0.281 \quad(-3.47)$ & 3.604 \\
\hline D-9 & -0.028 & $(-0.32)$ & 0.080 & $(0.90)$ & 0.097 & $(1.30)$ & 3.061 & -0.182 & $(-1.88)$ & -0.106 & $(-1.09)$ & $-0.292 \quad(-3.53)$ & 3.601 \\
\hline D-8 & 0.121 & $(1.33)$ & 0.228 & $(2.49)$ & 0.199 & $(2.50)$ & 3.178 & -0.178 & $(-1.84)$ & -0.102 & $(-1.05)$ & $-0.172 \quad(-2.08)$ & 3.590 \\
\hline D-7 & 0.007 & $(0.07)$ & 0.114 & $(1.27)$ & 0.093 & $(1.22)$ & 3.112 & -0.244 & $(-2.54)$ & -0.165 & $(-1.70)$ & $-0.200 \quad(-2.43)$ & 3.579 \\
\hline D-6 & 0.119 & (1.33) & 0.225 & $(2.53)$ & 0.120 & $(1.52)$ & 3.128 & -0.339 & $(-3.51)$ & -0.262 & $(-2.71)$ & $-0.157 \quad(-1.91)$ & 3.560 \\
\hline D-5 & 0.161 & (1.78) & 0.266 & $(2.92)$ & 0.203 & $(2.58)$ & 3.154 & -0.437 & $(-4.59)$ & -0.361 & $(-3.79)$ & $-0.185 \quad(-2.20)$ & 3.511 \\
\hline D-4 & 0.179 & (1.99) & 0.285 & $(3.15)$ & 0.255 & $(3.31)$ & 3.141 & -0.303 & $(-3.13)$ & -0.228 & $(-2.34)$ & $-0.175 \quad(-1.99)$ & 3.598 \\
\hline D-3 & 0.289 & (3.19) & 0.394 & $(4.32)$ & 0.419 & $(5.17)$ & 3.218 & -0.616 & $(-6.29)$ & -0.540 & $(-5.49)$ & $-0.447 \quad(-5.43)$ & 3.678 \\
\hline D-2 & 0.341 & $(3.85)$ & 0.447 & $(5.01)$ & 0.517 & (6.68) & 3.112 & -0.530 & $(-5.42)$ & -0.454 & $(-4.62)$ & $-0.321 \quad(-3.83)$ & 3.680 \\
\hline D-1 & 0.243 & $(2.60)$ & 0.350 & $(3.73)$ & 0.554 & $(6.87)$ & 3.289 & -0.075 & $(-0.74)$ & 0.000 & $(0.00)$ & $-0.272 \quad(-3.07)$ & 3.777 \\
\hline D 0 & 0.470 & $(5.08)$ & 0.576 & $(6.28)$ & 0.892 & $(10.82)$ & 3.232 & 1.198 & $(11.45)$ & 1.274 & $(12.16)$ & $\begin{array}{ll}0.656 & (6.91) \\
\end{array}$ & 4.117 \\
\hline $\mathrm{D}+1$ & -0.373 & $(-3.98)$ & -0.267 & $(-2.83)$ & -0.436 & $(-5.23)$ & 3.322 & 0.798 & $(7.91)$ & 0.875 & $(8.65)$ & 0.803 & 3.893 \\
\hline $\mathrm{D}+2$ & -0.200 & $(-2.15)$ & -0.093 & $(-1.00)$ & -0.298 & $(-3.65)$ & 3.290 & 0.083 & $(0.84)$ & 0.160 & (1.61) & $(3.44)$ & 3.735 \\
\hline$D+3$ & -0.228 & $(-2.46)$ & -0.123 & $(-1.31)$ & -0.205 & $(-2.60)$ & 3.284 & 0.000 & $(0.00)$ & 0.075 & $(0.77)$ & $0.136 \quad(1.64)$ & 3.640 \\
\hline $\mathrm{D}+4$ & -0.242 & $(-2.64)$ & -0.136 & $(-1.47)$ & -0.118 & $(-1.45)$ & 3.211 & -0.114 & $(-1.17)$ & -0.039 & $(-0.39)$ & $-0.037 \quad(-0.44)$ & 3.667 \\
\hline $\mathrm{D}+5$ & -0.203 & $(-2.25)$ & -0.097 & $(-1.07)$ & -0.141 & $(-1.79)$ & 3.175 & -0.161 & $(-1.65)$ & -0.085 & $(-0.87)$ & $-0.045 \quad(-0.53)$ & 3.624 \\
\hline $\mathrm{D}+6$ & -0.220 & $(-2.38)$ & -0.116 & $(-1.25)$ & -0.120 & $(-1.42)$ & 3.223 & -0.153 & $(-1.56)$ & -0.077 & $(-0.79)$ & $-0.035 \quad(-0.42)$ & 3.626 \\
\hline $\mathrm{D}+7$ & -0.254 & $(-2.69)$ & -0.150 & $(-1.58)$ & -0.147 & $(-1.82)$ & 3.316 & -0.118 & $(-1.21)$ & -0.042 & $(-0.43)$ & $-0.093 \quad(-1.08)$ & 3.617 \\
\hline $\mathrm{D}+8$ & -0.260 & $(-2.82)$ & -0.155 & $(-1.66)$ & -0.203 & $(-2.47)$ & 3.259 & 0.297 & $(3.03)$ & 0.374 & (3.79) & $0.034 \quad(0.40)$ & 3.672 \\
\hline $\mathrm{D}+9$ & -0.079 & $(-0.84)$ & 0.025 & $(0.26)$ & -0.141 & $(-1.72)$ & 3.360 & 0.220 & (2.29) & 0.296 & (3.06) & 0.102 & 3.598 \\
\hline $\mathrm{D}+10$ & -0.062 & $(-0.67)$ & 0.043 & $(0.46)$ & -0.159 & $(-2.04)$ & 3.227 & 0.107 & $(1.12)$ & 0.183 & $(1.90)$ & $\begin{array}{ll}0.059 & (0.70) \\
\end{array}$ & 3.550 \\
\hline $\mathrm{CAR}(-10,-1)$ & 1.212 & $(3.58)$ & 2.265 & $(6.43)$ & 2.438 & $(8.86)$ & & -3.273 & $(-9.22)$ & -2.522 & $(-6.88)$ & $-2.467 \quad(-8.37)$ & \\
\hline $\mathrm{CAR}(0,+1)$ & 0.097 & $(0.73)$ & 0.309 & $(2.31)$ & 0.458 & $(3.83)$ & & 1.993 & (12.70) & 2.145 & (13.63) & $1.457(10.34)$ & \\
\hline $\operatorname{CAR}(0,+10)$ & -1.639 & $(-4.91)$ & -0.487 & $(-1.39)$ & -1.063 & $(-3.81)$ & & 2.150 & $(5.95)$ & 2.983 & $(7.91)$ & $1.883 \quad(6.32)$ & \\
\hline $\mathrm{CAR}(+1,+10)$ & -2.109 & $(-6.50)$ & -1.063 & $(-3.12)$ & -1.955 & $(-7.22)$ & & 0.952 & $(2.80)$ & 1.709 & $(4.82)$ & $1.226 \quad(4.32)$ & \\
\hline
\end{tabular}


Table 6. (Continued)

Panel C. Foreigners normalized order-imbalances matched with domestic institutions

\begin{tabular}{|c|c|c|c|c|c|c|c|c|c|c|c|c|c|c|c|c|c|c|c|c|}
\hline \multirow[b]{2}{*}{ Event Day } & \multicolumn{10}{|c|}{ Net Buy $(\mathrm{N}=1,451)$} & \multicolumn{10}{|c|}{ Net Sell $(\mathrm{N}=1,594)$} \\
\hline & \multicolumn{2}{|c|}{$\begin{array}{r}\text { Foreigner } \\
\text { Mean-Adj } \\
\text { Ret } \\
\end{array}$} & \multicolumn{2}{|c|}{$\begin{array}{r}\text { Institution } \\
\text { Mean-Adj Ret }\end{array}$} & \multicolumn{2}{|c|}{ Difference } & \multicolumn{2}{|c|}{$\begin{array}{l}\text { Cumulative } \\
\text { Difference }\end{array}$} & \multicolumn{2}{|c|}{$\begin{array}{r}\text { Difference in } \\
\text { |Mean-Adj Ret }\end{array}$} & \multicolumn{2}{|c|}{$\begin{array}{r}\text { Foreigner } \\
\text { Mean-Adj } \\
\text { Ret } \\
\end{array}$} & \multicolumn{2}{|c|}{$\begin{array}{r}\text { Institution } \\
\text { Mean-Adj Ret }\end{array}$} & \multicolumn{2}{|c|}{ Difference } & \multicolumn{2}{|c|}{$\begin{array}{c}\text { Cumulative } \\
\text { Difference }\end{array}$} & \multicolumn{2}{|c|}{$\begin{array}{c}\text { Difference in } \\
\text { |Mean-Adj Ret } \mid\end{array}$} \\
\hline D-10 & 0.142 & $(1.32)$ & -0.020 & $(-0.19)$ & 0.157 & $(1.04)$ & 0.157 & $(1.04)$ & 0.055 & $(0.55)$ & -0.069 & $(-0.66)$ & 0.047 & $(0.41)$ & -0.102 & $(-0.66)$ & -0.102 & $(-0.66)$ & -0.384 & $-3.93)$ \\
\hline D-9 & 0.082 & $0.76)$ & 0.078 & $(0.73)$ & .001 & 1) & 0.130 & $(0$. & 0.135 & & -0.157 & $(-1.48)$ & 0.117 & $(1.02)$ & & & -0.389 & & -0.260 & \\
\hline D- 8 & 0.009 & $(0.08)$ & 0.087 & $(0.77)$ & -0.073 & 6) & 0.030 & $(0$. & -0.137 & $(-1.36)$ & -0.133 & $(-1.26)$ & 0.116 & $(1.03)$ & -0.240 & $(-1.52)$ & -0.643 & & -0.170 & \\
\hline $\mathrm{D}-7$ & 128 & $(1.22)$ & .142 & $(1.32)$ & & & 0.070 & & -0.073 & & -0.013 & & -0.031 & $(-0.28)$ & 0.025 & & -0.725 & & -0.165 & \\
\hline $\mathrm{D}-$ & 205 & $(1.9$ & 0.101 & $(0.9$ & 0.098 & $(0$. & 0.178 & $(0$. & -0.031 & 31) & -0.337 & & 0.026 & $(0.23)$ & -0.373 & & -1.143 & & -0.233 & \\
\hline D-5 & 0.327 & $(3.06)$ & 0.334 & (3.11) & -0.009 & $(-0.06)$ & 0.158 & $(0.37)$ & -0.024 & $(-0.25)$ & -0.343 & $(-3.18)$ & -0.189 & $(-1.66)$ & -0.170 & & -1.212 & & -0.144 & \\
\hline D-4 & 0.287 & (2.64) & 0.454 & (4.16) & -0.178 & $(-1.17)$ & -0.013 & $(-0.03)$ & 0.001 & & -0.126 & & 0.102 & $(0.90)$ & -0.213 & & -1.333 & $(-2.60)$ & -0.244 & \\
\hline D-3 & 0.115 & $(1.11)$ & 0.252 & $(2.24)$ & -0.154 & $(-1.02)$ & -0.123 & $(-0.26)$ & -0.239 & $(-2.51)$ & -0.386 & $(-3.58)$ & -0.128 & $(-1.12)$ & -0.252 & $(-1.62)$ & -1.690 & & -0.215 & \\
\hline D-2 & 0.477 & $(4.49)$ & 0.661 & (6.09) & -0.172 & $(-1.13)$ & -0.384 & $(-0.76)$ & -0.107 & $(-1.11)$ & -0.472 & $(-4.18)$ & -0.572 & $(-4.98)$ & 0.092 & $(0.57)$ & -1.5 & & -0.105 & $(-0.99)$ \\
\hline D-1 & 0.609 & $(5.71)$ & 0.508 & $(4.72)$ & 0.103 & $(0.69)$ & -0.355 & $(-0.66)$ & -0.003 & $(-0.03)$ & -0.428 & $(-3.70)$ & 0.134 & $(1.12)$ & -0.559 & $(-3.41)$ & -1.912 & $(-3.18)$ & -0.046 & $(-0.43)$ \\
\hline $\mathrm{D} 0$ & 1.198 & $(11.28)$ & 0.961 & $(8.80)$ & 0.237 & $(1.63)$ & -0.083 & $(-0.15)$ & -0.031 & $(-0.31)$ & -0.232 & $(-1.96)$ & 0.886 & $(7.20)$ & -1.118 & $(-6.91)$ & -2.833 & $(-4.61)$ & -0.216 & $(-2.09)$ \\
\hline $\mathrm{D}+1$ & 0.004 & & -0.225 & $(-2.10)$ & & & & & -0.016 & & 0.502 & & 0.524 & & & & & & -0.147 & \\
\hline$D+2$ & 0.048 & $(0.46)$ & 0.246 & $(-2.17)$ & 0.299 & & 0.6 & (1. & -0.230 & & -0.051 & $(-0$. & 0.052 & $(0$. & 103 & & -2.7 & & -0.089 & \\
\hline$D+3$ & -0.254 & $(-2.43)$ & -0.117 & $(-1.02)$ & -0.144 & $(-0.9$ & 0.553 & $(0.8$ & -0.293 & $(-2.90)$ & -0.091 & $(-0.83)$ & 0.255 & $(2.26)$ & -0.354 & $(-2.27)$ & -3.069 & $(-4.37)$ & -0.167 & \\
\hline $\mathrm{D}+4$ & -0.133 & $(-1.26)$ & -0.238 & $(-2.13)$ & 0.116 & $(0.76)$ & 0.812 & $(1.23)$ & -0.228 & $(-2.24)$ & -0.023 & $(-0.21)$ & 0.157 & $(1.40)$ & -0.184 & $(-1.17)$ & -3.172 & $(-4.33)$ & -0.159 & $(-1.55)$ \\
\hline $\mathrm{D}+5$ & -0.115 & $(-1.09)$ & -0.211 & $(-1.93)$ & 0.102 & $(0.66)$ & 0.846 & $(1.22)$ & -0.154 & & -0.120 & $(-1.10)$ & -0.033 & $(-0.29)$ & -0.085 & & -3.113 & & -0.160 & \\
\hline $\mathrm{D}+6$ & 0.099 & $(0.99)$ & -0.281 & $(-2.55)$ & 0.378 & $(2.52)$ & 1.221 & (1.71) & -0.359 & $(-3.62)$ & -0.278 & $(-2.57)$ & 0.065 & $(0.57)$ & -0.358 & $(-2.24)$ & -3.682 & $(-4.59)$ & -0.241 & $(-2.32)$ \\
\hline $\mathrm{D}+7$ & -0.093 & $(-0.89)$ & -0.154 & $(-1.38)$ & 0.048 & $(0.31)$ & 1.440 & (1.94) & -0.281 & $(-2.83)$ & -0.125 & $(-1.13)$ & 0.023 & $(0.20)$ & -0.138 & $(-0.86)$ & -3.714 & $(-4.54)$ & -0.213 & $(-2.09)$ \\
\hline $\mathrm{D}+8$ & -0.161 & $(-1.59)$ & -0.317 & $(-2.87)$ & 0.139 & $(0.94)$ & 1.537 & (1.98) & -0.246 & $(-2.45)$ & -0.167 & $(-1.57)$ & 0.282 & $(2.38)$ & -0.444 & $(-2.81)$ & -4.015 & $(-4.76)$ & -0.426 & $(-4.13)$ \\
\hline $\mathrm{D}+9$ & 0.024 & $(0.22)$ & -0.003 & $(-0.03)$ & 0.049 & $(0.32)$ & 1.596 & $(2.00)$ & -0.094 & $(-0.95)$ & -0.127 & $(-1.13)$ & 0.444 & $(3.92)$ & -0.574 & $(-3.55)$ & -4.329 & $(-4.96)$ & -0.042 & $(-0.41)$ \\
\hline $\mathrm{D}+10$ & -0.075 & $(-0.72)$ & 0.033 & $(0.30)$ & -0.090 & $(-0.60)$ & 1.669 & $(2.06)$ & -0.189 & $(-1.92)$ & 0.048 & $(0.43)$ & 0.015 & $(0.13)$ & 0.018 & $(0.12)$ & -4.270 & $(-4.80)$ & 0.043 & $(0.43)$ \\
\hline$\overline{\mathrm{CAR}}(-10,-1)$ & 2.370 & $(6.27)$ & 2.589 & $(6.45)$ & -0.222 & $(-0.42)$ & & & & & -2.448 & $(-5.96)$ & -0.373 & $(-0.85)$ & -2.002 & $(-3.44)$ & & & & \\
\hline $\operatorname{CAR}(0,+1)$ & 1.201 & (7.57) & 0.735 & (4.70) & 0.468 & $(2.12)$ & & & & & 0.269 & (1.56) & 1.408 & $(7.87)$ & -1.137 & $(-4.75)$ & & & & \\
\hline $\operatorname{CAR}(0,+10)$ & 0.548 & (1.39) & -0.793 & $(-1.89)$ & 1.357 & (2.41) & & & & & -0.659 & $(-1.59)$ & 2.664 & $(6.03)$ & -3.340 & & & & & \\
\hline $\operatorname{CAR}(+1,+10)$ & -0.650 & $(-1.74)$ & -1.754 & $(-4.28)$ & 1.120 & $(2.06)$ & & & & & -0.427 & $(-1.08)$ & 1.778 & $(4.27)$ & -2.222 & $(-3.87)$ & & & & \\
\hline
\end{tabular}


Table 6. (Continued)

Panel D. Domestic individuals normalized order-imbalance events

\begin{tabular}{|c|c|c|c|c|c|c|c|c|}
\hline \multirow{3}{*}{$\begin{array}{c}\text { Event Day } \\
\text { D-10 }\end{array}$} & \multicolumn{4}{|c|}{ Net Buy $(\mathrm{N}=2,328)$} & \multicolumn{4}{|c|}{ Net Sell $(\mathrm{N}=2,191)$} \\
\hline & Raw ret & Mean-adj ret & \multicolumn{2}{|c|}{$\begin{array}{c}\text { Market-adj ret |Mean-adj } \\
\text { ret| }\end{array}$} & Raw ret & Mean-adj ret & \multicolumn{2}{|c|}{$\begin{array}{c}\text { Market-adj ret|Mean-adj } \\
\text { ret| }\end{array}$} \\
\hline & $-0.531 \quad(-5.42)$ & $-0.452 \quad(-4.60)$ & $-0.312 \quad(-3.87)$ & 3.646 & $-0.181 \quad(-2.06)$ & $-0.085 \quad(-0.96)$ & $0.021 \quad(0.28)$ & 3.133 \\
\hline D-9 & $-0.177 \quad(-1.81)$ & $-0.098 \quad(-1.00)$ & $-0.262 \quad(-3.16)$ & 3.693 & $0.009 \quad(0.10)$ & $0.107 \quad(1.18)$ & 0.180 & 3.205 \\
\hline D-8 & $-0.130 \quad(-1.35)$ & $-0.050 \quad(-0.51)$ & $-0.123 \quad(-1.53)$ & 3.591 & $(0.43)$ & $0.136 \quad(1.49)$ & 0.193 & 3.192 \\
\hline D-7 & $-0.283 \quad(-2.93)$ & $-0.199 \quad(-2.05)$ & $-0.277 \quad(-3.32)$ & 3.601 & $-0.130 \quad(-1.45)$ & $-0.032 \quad(-0.36)$ & 0.041 & 3.141 \\
\hline D-6 & $-0.599 \quad(-6.18)$ & $-0.518 \quad(-5.36)$ & $-0.320 \quad(-3.86)$ & 3.597 & $0.052 \quad(0.57)$ & $0.149 \quad(1.66)$ & $(0.76)$ & 3.193 \\
\hline D-5 & $-0.578 \quad(-6.01)$ & $-0.498 \quad(-5.17)$ & $-0.247 \quad(-3.00)$ & 3.580 & $(1.92)$ & $(2.96)$ & $(3.26)$ & 3.229 \\
\hline D-4 & $-0.408 \quad(-4.22)$ & $-0.328 \quad(-3.37)$ & $-0.236 \quad(-2.75)$ & 3.628 & $(1.58)$ & $(2.65)$ & (3.89) & 3.179 \\
\hline D-3 & $-0.781 \quad(-7.96)$ & $-0.700 \quad(-7.11)$ & $-0.605 \quad(-7.38)$ & 3.700 & $(3.25)$ & $(4.30)$ & 0.435 & 3.217 \\
\hline D-2 & $-0.916 \quad(-9.13)$ & $-0.834 \quad(-8.29)$ & $-0.564 \quad(-6.70)$ & 3.851 & $(4.26)$ & $(5.32)$ & 0.508 & 3.139 \\
\hline D-1 & $-0.403 \quad(-3.92)$ & $-0.322 \quad(-3.12)$ & $-0.561 \quad(-6.41)$ & 3.896 & $(3.61)$ & $(4.65)$ & $0.543 \quad(6.80)$ & 3.282 \\
\hline $\mathrm{D} 0$ & $\begin{array}{ll}0.888 & (8.18) \\
\end{array}$ & $0.968 \quad(8.92)$ & $\begin{array}{ll}0.235 & (2.40) \\
\end{array}$ & 4.280 & $(6.78)$ & $(7.89)$ & $1.165(14.13)$ & 3.296 \\
\hline $\mathrm{D}+1$ & $(7.98)$ & $(8.76)$ & $(9.39)$ & 3.960 & $-0.353 \quad(-3.75)$ & $-0.256 \quad(-2.71)$ & $-0.386 \quad(-4.56)$ & 3.371 \\
\hline $\mathrm{D}+2$ & $(0.82)$ & 0.165 & $(3.85)$ & 3.902 & $-0.153 \quad(-1.65)$ & $-0.057 \quad(-0.61)$ & $-0.294 \quad(-3.59)$ & 3.316 \\
\hline$D+3$ & $(0.09)$ & $(0.89)$ & $(2.78)$ & 3.736 & $-0.223 \quad(-2.41)$ & $-0.127 \quad(-1.37)$ & $-0.242 \quad(-3.03)$ & 3.328 \\
\hline $\mathrm{D}+4$ & $0.029 \quad(0.29)$ & $0.109 \quad(1.09)$ & $(0.47)$ & 3.765 & $-0.334 \quad(-3.65)$ & $-0.238 \quad(-2.57)$ & $-0.232 \quad(-2.83)$ & 3.266 \\
\hline $\mathrm{D}+5$ & $-0.155 \quad(-1.55)$ & $-0.074 \quad(-0.74)$ & $(0.56)$ & 3.719 & $-0.150 \quad(-1.67)$ & $-0.054 \quad(-0.59)$ & $-0.124 \quad(-1.60)$ & 3.204 \\
\hline $\mathrm{D}+6$ & $-0.137 \quad(-1.37)$ & $-0.057 \quad(-0.57)$ & $0.107 \quad(1.29)$ & 3.730 & $-0.151 \quad(-1.63)$ & $-0.055 \quad(-0.60)$ & $-0.125 \quad(-1.51)$ & 3.257 \\
\hline $\mathrm{D}+7$ & $-0.100 \quad(-1.01)$ & $-0.020 \quad(-0.20)$ & $-0.042 \quad(-0.49)$ & 3.736 & $-0.223 \quad(-2.39)$ & $-0.127 \quad(-1.36)$ & $-0.116 \quad(-1.45)$ & 3.304 \\
\hline $\mathrm{D}+8$ & $0.336 \quad(3.40)$ & $0.415 \quad(4.17)$ & $0.149 \quad(1.79)$ & 3.727 & $-0.402 \quad(-4.38)$ & $-0.306 \quad(-3.31)$ & $-0.294 \quad(-3.64)$ & 3.279 \\
\hline $\mathrm{D}+9$ & 0.086 & (1.67) & (1.01) & 3.716 & $-0.173 \quad(-1.85)$ & $-0.078 \quad(-0.83)$ & $-0.177 \quad(-2.18)$ & 3.349 \\
\hline $\mathrm{D}+10$ & $0.185 \quad(1.87)$ & $0.264 \quad(2.65)$ & $(1.82)$ & 3.745 & $-0.138 \quad(-1.50)$ & $-0.043 \quad(-0.47)$ & $-0.211(-2.68)$ & 3.232 \\
\hline $\operatorname{CAR}(-10,-1)$ & $-4.734(-13.21)$ & $-3.942(-10.67)$ & $-3.459(-11.71)$ & & $1.097 \quad(3.26)$ & $2.057 \quad(5.88)$ & $2.519 \quad(8.99)$ & \\
\hline $\mathrm{CAR}(0,+1)$ & $1.696(10.65)$ & 1.857 (11.64) & $1.097 \quad(7.67)$ & & $0.279 \quad(2.03)$ & $0.472 \quad(3.45)$ & $0.780 \quad(6.38)$ & \\
\hline $\operatorname{CAR}(0,+10)$ & $2.030 \quad(5.39)$ & $2.907 \quad(7.42)$ & (7.18) & & $-1.654 \quad(-4.91)$ & $-0.607 \quad(-1.72)$ & $-1.023 \quad(-3.67)$ & \\
\hline $\operatorname{CAR}(+1,+10)$ & $1.143 \quad(3.25)$ & $1.939 \quad(5.29)$ & $(6.76)$ & & $-2.285(-7.04)$ & $-1.334 \quad(-3.90)$ & $-2.188 \quad(-8.16)$ & \\
\hline
\end{tabular}




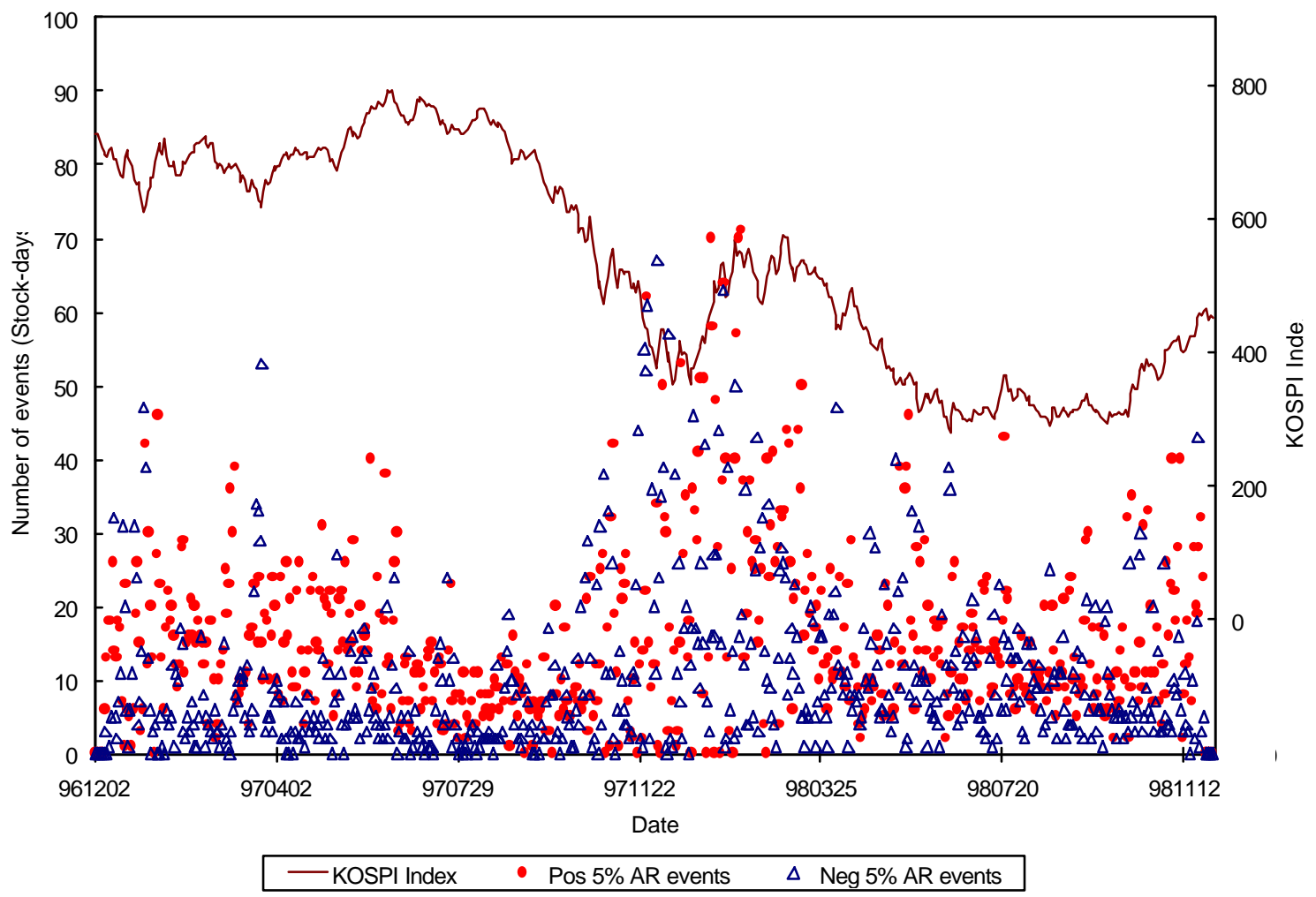

Figure 1. Number of events (stock-days) with large abnormal returns (961202 981130: 586 days) 